In Cooperation with the National Park Service

\title{
Gravity Investigations of the Chickasaw National Recreation Area, south-central Oklahoma
}

By Daniel S. Scheirer and Allegra Hosford Scheirer

Any use of trade, firm, or product names is for descriptive purposes only and does not imply endorsement by the U.S. Government

Open-File Report 2006-1083

U.S. Department of the Interior U.S. Geological Survey 


\section{Contents}

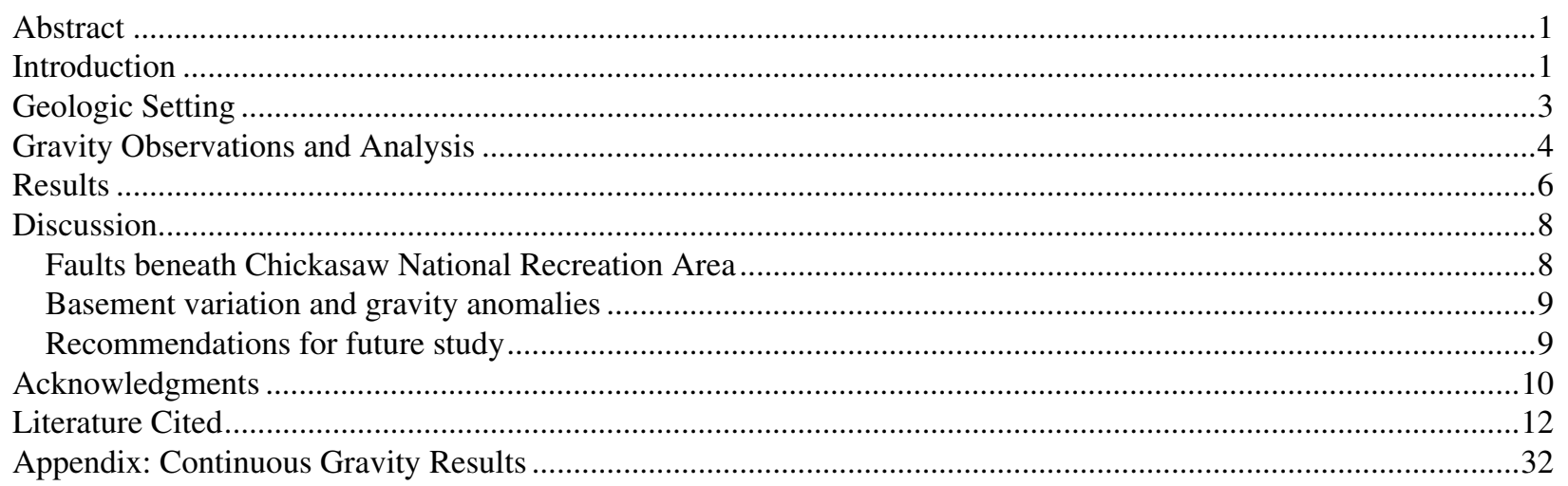

\section{Figures}

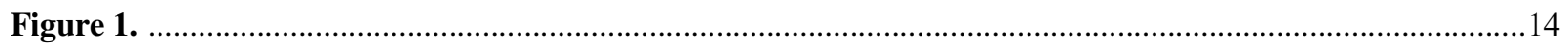

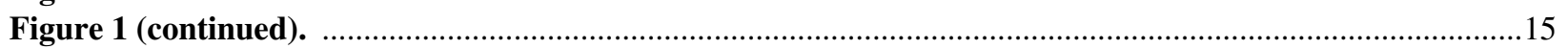

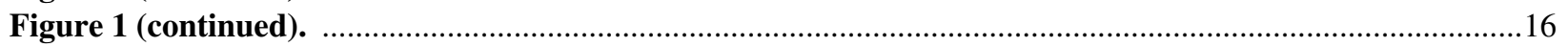

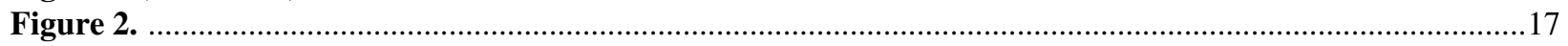

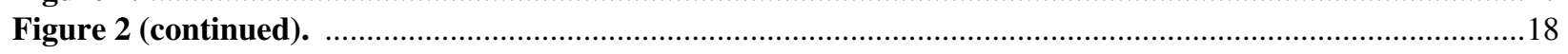

Figure 3.

Figure 4.

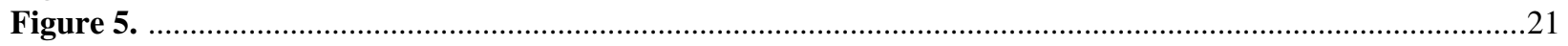

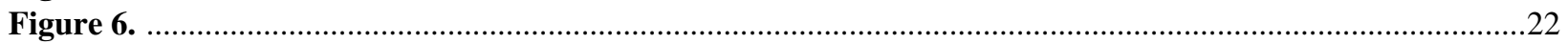

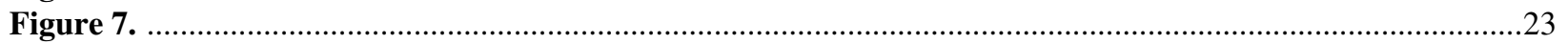

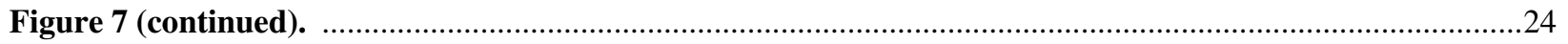

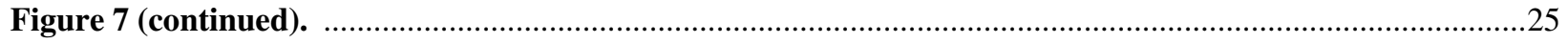

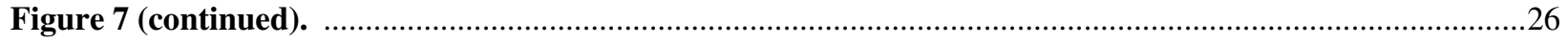

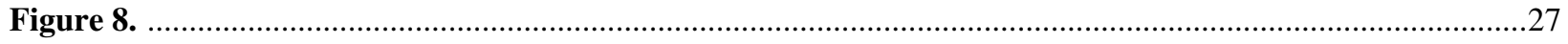

Figure 9.

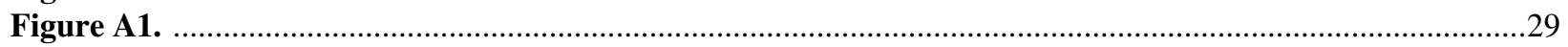

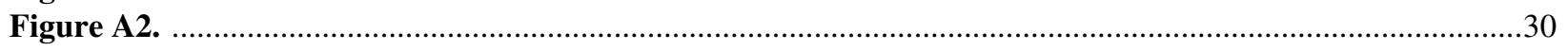

Figure A3.

\section{Tables}

Table 1. Depth to base of Vanoss Formation (and top of Arbuckle Group) rocks in three wells in CNRA ...............11

Table 2. Physical properties of rock samples grouped by stratigraphic unit .......................................................11

Table 3. Gravity base stations used for data collected in 2004 and 2005 ............................................................11

Table A1. Principal facts for gravity stations collected in 2004 and 2005 in south-central Oklahoma ......................35

Table A2. Physical property measurements of rock samples collected in 2004 and 2005 ......................................40 


\title{
Gravity Investigations of the Chickasaw National Recreation Area, south-central Oklahoma
}

\author{
By Daniel S. Scheirer and Allegra Hosford Scheirer
}

\begin{abstract}
The geological configuration of the Arbuckle Uplift in the vicinity of Chickasaw National Recreation Area in south-central Oklahoma plays a governing role in the distribution of fresh and mineral springs within the park and in the existence of artesian wells in and around the park. A confining layer of well-cemented conglomerate lies immediately below the surface of the recreation area, and groundwater migrates from an area of meteoric recharge where rocks of the Arbuckle-Simpson Aquifer crop out as close as two kilometers to the east of the park.

Prominent, Pennsylvanian-aged faults are exposed in the aquifer outcrop, and two of the fault traces project beneath the conglomerate cover toward two groups of springs within the northern section of the park. We conducted gravity fieldwork and analysis to investigate the subsurface extensions of these major faults beneath Chickasaw National Recreation Area. By defining gravity signatures of the faults where they are exposed, we infer that the Sulphur and Mill Creek Faults bend to the south-west where they are buried. The South Sulphur Fault may project westward linearly if it juxtaposes rocks that have a density contrast opposite that of that fault's density configuration in the Sulphur Syncline area. The Sulphur Syncline, whose eastern extent is exposed in the outcrop area of the ArbuckleSimpson Aquifer, does not appear to extend beneath Chickasaw National Recreation Area nor the adjacent City of Sulphur. The South Sulphur Fault dips steeply northward, and its normal sense of offset suggests that the Sulphur Syncline is part of a graben. The Mill Creek Fault dips vertically, and the Reagan Fault dips southward, consistent with its being mapped as a thrust fault. The Sulphur and Mill Creek Synclines may have formed as pull-apart basins in a left-lateral, left-stepping strike-slip environment. The character of the gravity field of Chickasaw National Recreation Area is different from the lineated gravity field in the area of Arbuckle-Simpson Aquifer outcrop. This change in character is not due to the presence of the overlying conglomerate layer, which is quite thin $(<100 \mathrm{~m})$ in the area of the park with the springs. The presence of relatively high-density Precambrian basement rocks in a broader region suggests that significant gravity anomalies may arise from variations in basement topography. Understanding of the geological configuration of Chickasaw National Recreation Area can be improved by expanding the study area and by investigating complementary geophysical and borehole constraints of the subsurface.
\end{abstract}

\section{Introduction}

Chickasaw National Recreation Area (CNRA) was established over a century ago to protect the natural, cultural, and recreational resources of an area of south-central Oklahoma that is rich in springs, streams, and artesian wells (fig. 1a) (Gould and Schoff, 1939; Hanson and Cates, 1994). The juxtaposition of eastern forest and western prairie ecosystems yields a unique array of flora and fauna in the Midcontinent, and mineral and fresh water springs have attracted people to this area for centuries. Studies of the hydrology of CNRA and its vicinity have been important since its inception (for example, Gould, 1906; Gould and Schoff, 1939; Hart, 1974; Goemaat and Willard, 1983; Fairchild and others, 1990; Hanson and Cates, 1994), with goals of understanding the natural variability of groundwater and surface water flows and compositions, and of estimating the impact of water usage outside of CNRA to water features within the park. The geologic configuration (figs. 1b, 1c) of CNRA, the adjacent City of Sulphur, and the surrounding regions has long been recognized as a primary control on groundwater flow in this 
region, connecting areas of outcrop of the Arbuckle-Simpson Aquifer to the east of CNRA where there is meteoric recharge with areas beneath the park where the aquifer is confined. The aims of the geophysical study described in this report are to elucidate the geologic structures in the subsurface that might be important in promoting or impeding groundwater flow into and within CNRA. The focus of this study is in the northern section of CNRA the Travertine District - where the springs occur.

The hydrogeology of CNRA was comprehensively described by Hanson and Cates (1994), and the aspects that are important to ground and spring waters are summarized in this paragraph. Precipitation recharges the Arbuckle-Simpson Aquifer where it crops out in a broad area of elevated topography to the east of CNRA; this outcrop area is named the Hunton Anticline (fig. 2). The Arbuckle-Simpson Aquifer outcrop of predominantly carbonate rocks, with lesser sandstone and shale units (fig. 3), extends to within about $2 \mathrm{~km}$ of the Travertine District, where Arbuckle-Simpson Aquifer units dip westward unconformably beneath a thickening wedge of younger, tightly-cemented conglomerate (fig. 1b). Prominent faults segment the Arbuckle-Simpson Aquifer lithologic units into distinct blocks. The overlying conglomerate of the Vanoss Formation acts as a confining layer to the Arbuckle-Simpson Aquifer, and the intersection of the potentiometric surface of the aquifer with the land surface produces the springs within CNRA. Wells that penetrate into the Arbuckle-Simpson Aquifer are commonly artesian, especially at lower ground elevations. Two fresh water, bicarbonate-type springs, Buffalo and Antelope, are located in the eastern Travertine District (fig. 1c), and they have 1 to 2 orders of magnitude greater discharge than the mineral springs of the park. The mineral springs are located in the central and western Travertine District (fig. 1c). Those in the west (Bromide and Medicine) have greater salinity and total dissolved solid content than those in the center. This configuration has led to the suggestion that fresh and mineralized groundwaters mix in the center of the Travertine District (for example, Hanson and Cates, 1994). Water wells tapping the Arbuckle-Simpson Aquifer in the Sulphur area have water compositions that mimic the general east-to-west gradient, from fresher to more mineralized, of the springs. The best-known well, Vendome Well, was originally drilled in 1922, and it supplied a public swimming pool for about 50 years. Vendome Well is now within the Travertine District of CNRA, and it continues artesian flow.

Flow in the springs and wells has varied significantly over the past century. On numerous occasions, flow in Buffalo and Antelope Springs ceased; these periods are well-correlated with times of drought (Hanson and Cates, 1994). Relative to the fresh water springs, discharge at the mineral springs and the artesian wells is less correlated with precipitation, but flow of mineralized waters has nonetheless varied significantly. Many wells were artesian when drilled in the first half of the $20^{\text {th }}$ century, but now they must be pumped to produce water. An initial census of springs within the park included 33 active springs (Gould, 1906). In 1939 only 19 could be located (Gould and Schoff, 1939), and in 1987 about 7 were reported to have measurable flow (Hanson and Cates, 1994). There are several reasons for the decreases in the spring counts: in the 1930's, flows of neighboring diffuse springs were combined into single outlet constructions; trees planted in the same decade increased transpiration rates; and many artesian wells were drilled in the vicinity of the park in the 1920's and 1930's and their flows were unrestricted. While the number of flowing mineral springs has decreased through the years in part because of man-made plumbing changes, their collective discharge has substantially decreased due to other causes. For example, Gould and Schoff (1939) estimate that the flow rates of the mineral springs decreased by about $80 \%$ over the prior three decades. Hanson and Cates (1994) report that impacts of pumping at City of Sulphur water wells and Oklahoma Gas and Electric wells to the north of the Travertine District were not discernible at wells and springs within CNRA, although they suggest that there may be impact during prolonged dry periods. They suggest, like prior authors, that unrestricted flow from artesian wells may be responsible for decreased discharge of springs within CNRA. In the broader Arbuckle-Simpson Aquifer area, applications to remove groundwater from the Hunton Anticline to supply communities in other parts of Oklahoma led to the passage of Senate Bill 288 by the Oklahoma State Legislature in May 2003. Among other items, this Law initiated a comprehensive study of Arbuckle-Simpson Aquifer hydrology to allow more informed management and protection of the region's water resources (Oklahoma Water Resources Board, 2003).

To delineate subsurface structures that might be important for groundwater flow, Steven Cates conducted a study of CNRA based on gravity and magnetic observations and on structural geology (Cates, 1989). Using geophysical observations, modeling, and borehole information, he endeavored to define the geometry of faults and crustal blocks where they are obscured by Vanoss Formation. In 2004, the National Park Service funded the U.S. Geological Survey to conduct additional gravity investigations in and around CNRA, and this report documents new insights about the subsurface from these recent studies. 


\section{Geologic Setting}

Chickasaw National Recreation Area is situated on a portion of the northern margin of the Southern Oklahoma Aulacogen (Hoffman and others, 1974), a Cambrian rift that initiated a long history of marine sedimentation, followed by a structural inversion during Pennsylvanian orogenies and finally erosion to its current level. The geology of the region, termed the Arbuckle Uplift, has been extensively studied (for example, Taff, 1904, 1928; Ham, 1950), and most geological maps of the area derive from Ham and others (1954) (fig. 2b). More recent, detailed geological studies of Paleozoic stratigraphy, oil basins surrounding the outcrop area of the ArbuckleSimpson Aquifer, and quarries within the outcrop area are available, as are numerous geological summaries and field guides and some reinterpretations of regional geology in a plate tectonic context.

The Arbuckle Uplift is one of the few structural highs where Precambrian basement rocks are exposed in the Midcontinent. The uplift area, also termed the Arbuckle Mountains, is comprised of three major structural elements: from west to east, these are the Arbuckle Anticline, the Tishomingo Anticline, and the Hunton Anticline (fig. 2). These structures are variably deformed, are separated by major Paleozoic fault zones, and are surrounded by deposits of younger, minimally-deformed sedimentary rocks. The Hunton Anticline region (fig. 2) is comprised of a number of smaller structural units, including the Sulphur and Mill Creek Synclines and the Belton Anticline on its western margin near CNRA (fig. 1).

Precambrian granitic and granite-gneiss basement is present in the eastern portion of the Tishomingo Anticline (fig. 2b) and has been dated at 1,350 Ma (Ham and others, 1964). The next younger unit present in the Arbuckle Uplift is the Colbert Rhyolite that erupted within the active rift graben in the Cambrian. This igneous activity was followed by a long period of widespread marine deposition of primarily carbonate units in Cambrian through early Ordovician times (rocks of the Timbered Hills Group and the Arbuckle Group) followed by deposition of carbonate, sandstone, and shale units in middle Ordovician (the Simpson Group) through early Pennsylvanian times (fig. 3). Early Paleozoic sediment accumulation in the area of the present-day Arbuckle Anticline was much greater than in other areas of the uplift because of enhanced subsidence of the aulacogen trough. Over $11 \mathrm{~km}$ of sediment accumulated in the axis of the aulacogen in Cambrian through Pennsylvanian times, while the accumulation on the Hunton Anticline, considered to be on stable continental shelf was about one quarter as much (Ham, 1969). In Pennsylvanian time, a series of orogenies deformed the earlier Paleozoic sedimentary section, first uplifting the Hunton Anticline and then culminating in the late Pennsylvanian Arbuckle Orogeny, which produced intense thrust faulting and folding that formed the Arbuckle Anticline (fig. 2). The Washita Valley Fault Zone is thought to be the northern boundary of the aulacogen rift (fig. 2), and this Cambrian extensional structure was likely reactivated as a steep reverse and strike-slip fault in Pennsylvanian time. The syn- and post-tectonic erosional products of the Arbuckle Mountains are preserved as proximal coarse-grained clastic rocks. In the vicinity of CNRA, these rocks primarily consist of the conglomerate of the Vanoss Formation. The conglomerate forms a thin veneer over older Paleozoic units in the Travertine District of CNRA. In water wells in central and eastern Travertine District, the base of the Vanoss Formation occurs within $100 \mathrm{~m}$ of the surface (table 1). At the base of a meander scarp (figs. 1b, 1c), Rock Creek has eroded through Vanoss Formation to expose small outcrops of Ordovician rocks within CNRA (Cates, 1989; Johnson, 1990).

The rocks of the Arbuckle Group are carbonates, dominantly limestones in the western portion of the Arbuckle Uplift and dolomites in the Hunton Anticline region. Karst features are present in some locales. Rocks of the Simpson Group overlie the Arbuckle Group and include carbonates, but clastic units such as quartz sands and shales become increasingly common. The hydrologic properties of the rocks of the Arbuckle and Simpson Groups, along with those of the thinner and older Timbered Hills Group, are similar, and most investigators include these units in the definition of the Arbuckle-Simpson Aquifer (fig. 3).

Faulting during the Pennsylvanian orogenies was complex. Major faults and fault zones that offset stratigraphic units and that are exposed over scales of tens of kilometers are highlighted in the geologic maps of Figures 1 and 2 . These faults are oriented consistently $\sim \mathrm{N} 70 \mathrm{~W}$, and they are considered to be the result of widespread wrench and thrust deformation. Based on stratigraphic offsets, wrench (strike-slip) offsets are interpreted to be in a left-lateral sense and are estimated to range from a few kilometers to perhaps $60 \mathrm{~km}$ for individual faults (Ham, 1955; Tanner, 1967). Fault dip was not determined in early geologic mapping. A predominance of thrust deformation, versus earlier interpretations of strike-slip faulting, has been suggested by Denison (1982) and Brown (1984), who infer that some of the apparent left-lateral offset of units across the faults may arise from juxtaposition of previously-dipping units by the thrust motion. Numerous smaller faults are present 
throughout the Arbuckle Uplift and are displayed as dashed lines in the geological maps of this report. These subsidiary faults are characterized by short lengths, small offsets of stratigraphic units, and a wide range of orientations; they terminate against each other and against the major WNW-ESE oriented faults. The hydrologic importance of the major faults relative to their minor counterparts is unknown.

Two of the major faults exposed in the Hunton Anticline are close to the Travertine District of CNRA, and they have long been suspected as having a role in groundwater flow beneath CNRA. The main strand of the Sulphur Fault terminates in outcrop about $2 \mathrm{~km}$ east of CNRA, and it projects linearly to a position very near to the freshwater Buffalo and Antelope Springs in easternmost Travertine District (fig. 1c). The South Sulphur Fault projects to the mineral springs in the western Travertine District.

The variations in lithology across the study area are associated with changes in physical property values (table 2). In this area, the Precambrian basement has the greatest density (seen better in regional gravity variations than in table 2), and the Pennsylvanian coarse-grained clastic rocks have the lowest densities. Changes in density, especially at interfaces such as faults or basement contacts, produce gravity anomalies at the earth's surface that can be detected and characterized by gravity studies.

\section{Gravity Observations and Analysis}

In 2004 and 2005, the U.S. Geological Survey collected gravity observations in two field sessions, each utilizing two gravity meters: a conventional LaCoste-Romberg land G-meter and a continuous BGM-5 air/sea gravimeter. Our deployment of the latter instrument on a land vehicle is the first such deployment to our knowledge. This report will focus on results from the discrete gravimeter stations, and the Appendix summarizes the continuous gravimetry results to-date.

We collected gravity at 257 new stations (table A1) to supplement the 183 stations of Cates (1989) (fig. 4). In addition, we included 24 gravity stations from the GeoNet - United States Gravity Data Repository System compilation (http://paces.geo.utep.edu/gdrp/) for regional coverage. For the recent fieldwork (2004/2005), we established local gravity base stations in CNRA at Vendome Well, at the parking lot of Vendome Well, and at the Rock Creek Campground (table 3). Values of gravity at these local bases were tied to the IGSN71 gravity datum (Jablonski, 1974) via double-loop surveying to the permanent gravity base station at the Coalgate (Okla.) fire station. Cates (1989) also used a gravity base at Vendome Well for his surveying, but he assigned it an observed gravity value that differed from our calculated IGSN71 value by $28.8 \mathrm{mGal}$. To merge the new gravity stations with the Cates (1989) observations, we used that Vendome base difference as a constant correction for the Cates (1989) gravity values, and this correction resulted in acceptable matches of new and old observations across the entire study area. The 24 regional gravity stations did not require a gravity correction to provide a suitable match with the 2004/2005 gravity values.

Geographic positions of the new gravity stations were recorded with a Trimble GeoXT Global Positioning System (GPS) receiver. By using fixed GPS reference stations within $\sim 100 \mathrm{~km}$ of the gravity observations, latitude and longitude values were calculated via post-processing to have a precision generally better than 1 meter, and elevations had precisions of about 1 meter. Most LaCoste-Romberg stations were collected adjacent to the field vehicle, but in a number of instances we hiked to places that did not have road access. At gravity stations situated on rock outcrop, we collected 21 rock hand-samples, and we measured their density and magnetic susceptibility properties in the lab (Johnson and Olhoeft, 1984) (table A2). In addition, we measured the physical properties of 9 rocks collected for us by personnel of the Oklahoma Water Resources Board (OWRB).

Values of observed gravity were calculated at the new stations by accounting for tidal acceleration effects and for instrument drift constrained by gravity base ties at the beginning and end of each field day. We calculated a series of predictable gravity effects at all of the stations to account for: the global gravity field, the reduction in gravity with increasing elevation (free-air), the mass between the station and the geoid (simple Bouguer), the topographic variation near the station (terrain), and the compensating mass near the base of the crust (isostatic). (These effects are often termed corrections in the geophysical literature.) The final gravity anomaly after incorporation of these effects is termed the isostatic gravity anomaly, and it is useful for interpretation because it primarily reflects the density variations in the upper- and mid-crust (Simpson and others, 1986). For new gravity stations, field estimates were made of the terrain effect in a zone from the station out to a radius of $68 \mathrm{~m}$; for the 
Cates (1989) and GeoNet stations, this innermost terrain effect was not available. For all stations, digital terrain effects beyond $68 \mathrm{~m}$ were calculated from digital elevation models (DEMs) in two stages: from $68 \mathrm{~m}$ to $2 \mathrm{~km}$ and from $2 \mathrm{~km}$ to $167 \mathrm{~km}$ using the algorithms of Plouff (1977). Other parameters that were used in the calculation of gravity effects are typical for continental gravity studies; these include an upper crustal density of $2.67 \mathrm{~g} / \mathrm{cm}^{3}$, a mantle-crust density contrast of $0.4 \mathrm{~g} / \mathrm{cm}^{3}$, and a nominal crustal thickness at sea level of $25 \mathrm{~km}$. A typical uncertainty of a gravity anomaly from a new gravity stations is estimated to be $\sim 0.2 \mathrm{mGal}$, and uncertainty from a prior gravity station is more variable and thought to be somewhat larger. In all cases, the greatest component of gravity error arises from uncertainties in elevation.

Gravity station data were gridded with a $100 \mathrm{~m}$ spacing (fig. 5), which is somewhat finer than the average station-spacing. We investigated whether any of the stations had gravity values significantly different from their neighbors by upward-continuing (for example, Blakely, 1996) the isostatic gravity field by 100 to $500 \mathrm{~m}$, then calculated the difference between the original and upward-continued grids. This difference highlights shortwavelength anomalies in the grid, and in this way we determined that no such noisy stations were present. In another data validity test, we compared the tabulated elevations of the 464 gravity stations in the study area with elevations interpolated from $30 \mathrm{~m}$ DEMs, and in all cases, tabulated elevations were within $10 \mathrm{~m}$ of their DEM counterparts. For gravity stations collected in 2004 and 2005, virtually all were within 1 to $3 \mathrm{~m}$ of the DEM elevations, confirming the high quality of the elevations derived from the GeoXT system.

Gridded isostatic gravity anomaly data were used to detect significant lateral density interfaces in the subsurface using a maximum horizontal gradient technique (Blakely and Simpson, 1986). Maximum horizontal gradients of gravity fields are situated above vertical or near-vertical density boundaries in the subsurface, especially at shallow depths. The positions of local maxima of the gravity gradient can help delineate lithologic contacts at depth, especially those related to faults juxtaposing rocks of different densities. The magnitude of the gradient is a function of both the depth to the density boundary and the size of the density contrast. In practice, the presence of noise in the gravity grid may lead to false identifications of geological boundaries using this technique, so the interpretive power of this method is best where maximum gradients are spatially identified in clusters or lineaments.

To create models of the subsurface that can account for the observed gravity variation, we utilize a twodimensional forward modeling approach by configuring crustal blocks and adjusting their boundaries and densities such that their predicted gravitational effect matches the observed gravity anomaly at the surface (Talwani and others, 1959). A significant limitation of this gravity modeling is the non-uniqueness intrinsic to any potential field interpretation: in general, there are unlimited physical property configurations that can explain a given observation set. That said, by constraining the subsurface model geometry based on geologic mapping of significant features and based on realistic rock density values, important aspects of the subsurface may be surmised. Seven north-south profiles were selected for analysis (fig. 6). The profiles are separated by 1 minute in longitude and they correspond approximately to the mile-spaced section line roads where many of the stations were collected. In the east, these profiles cross the outcrop area of the Arbuckle-Simpson Aquifer and the major faults of the Pennsylvanian orogenies; towards the west, the profiles cover areas that are progressively buried by Vanoss Formation. An assumption of the profile analysis is that geologic structures are oriented perpendicular to the profiles; in our analysis, we make a geometric correction to account for the major fault directions that are oriented about $20^{\circ}$ from east-west. The western three profiles cross gravity anomalies that are oriented in a variety of directions, and twodimensional models of these lines are not as quantitatively reliable as those from where the anomalies are lineated.

Rock property measurements are presented in table A2 and are summarized in table 2 grouped by stratigraphy. While physical properties of individual hand-samples may not represent well the bulk properties of in situ volumes of rock, especially those at depth, the measurements can aid in characterizing the density variations among the units. The most common rock type sampled is carbonate, largely of dolomitic composition, with a saturated bulk density very similar to the $2.67 \mathrm{~g} / \mathrm{cm}^{3}$ assumed for the Bouguer and isostatic gravity calculations. The clastic rocks generally have densities 0.1 to $0.2 \mathrm{~g} / \mathrm{cm}^{3}$ lower than the $2.67 \mathrm{~g} / \mathrm{cm}^{3}$ Bouguer reduction density. The youngest rocks sampled, arkosic and conglomeratic units of the Vanoss Formation, generally have even lower densities. The densities of Precambrian granite samples average to about the Bouguer reduction density, and one of the Precambrian basement samples has the highest density measured in the sample suite. As discussed below, the pattern of gravity anomalies indicates that the in situ density of the basement rocks is on-average significantly greater than the density of the overlying carbonate and clastic units. In terms of magnetic properties, the basement rock samples are the only ones that have significantly non-zero magnetic susceptibilities (table 2). 


\section{Results}

The gridded isostatic gravity anomaly of CNRA and adjacent Hunton Anticline is illustrated in fig. 5. Two fundamental observations may be made: beneath the Hunton Anticline, gravity anomalies trend sub-parallel to the major WNW-ESE oriented faults, and west of the Hunton Anticline, gravity anomalies are less lineated and they do not correspond to simple, linear extensions of the anomalies beneath the anticline (a possible exception is noted below). Beneath the outcrop area of the Arbuckle-Simpson Aquifer, isostatic gravity lows correspond to structural lows; the Sulphur and Mill Creek Synclines are relative gravity lows, and the Belton and Tishomingo Anticlines are relative gravity highs. The magnitude of these gravity variations are 4 to $10 \mathrm{mGal}$, significantly greater than the uncertainty of the anomaly measurements. The positive gravity anomaly of the Tishomingo Anticline reflects the presence of dense Precambrian basement at the surface (fig. 2b) and in the shallow subsurface. The western portion of the Mill Creek Syncline is marked by an oval-shaped gravity low that extends to the southern portion of CNRA (fig. 5). Beneath CNRA, the isostatic gravity anomalies are broader and less lineated than those to the east. A relative gravity high is present beneath the City of Sulphur and the Travertine District of CNRA, a relative gravity low lies to the west of CNRA, and a SW-NE-trending high extends through the Park parallel to Rock Creek (fig. 5). The gravity high of the Belton Anticline merges with the perpendicularly-oriented Rock Creek gravity high; the gravity low of the Sulphur Syncline terminates before reaching the Travertine District of CNRA. The exception to the observation that gravity anomalies of the Arbuckle-Simpson Aquifer outcrop area do not extend linearly towards the WNW occurs where the gravity anomaly associated with the South Sulphur Fault is collinear with a gravity gradient of the opposite sense (positive isostatic gravity anomaly to the north, negative to the south) west of the Travertine District (fig. 5). This case and its significance will be discussed below.

A number of possible conclusions, some compatible with each other and others incompatible, can be drawn from the differing character of the gravity beneath the Hunton Anticline and that beneath CNRA. One alternative is that the tectonic structures of the Hunton Anticline region terminate or change trend near the edge of the ArbuckleSimpson Aquifer outcrop area. Another possibility is that a westward-thickening wedge of Vanoss Formation (table 1), having either homogeneous or heterogeneous density, obscures gravity signatures that may exist if the major faults extend linearly beneath CNRA. A final possibility is that the gravity anomalies beneath CNRA arise from deeper variations in basement topography. These possibilities will be explored below.

The positions and magnitudes of maximum horizontal isostatic gravity gradients (Blakely and Simpson, 1986) are illustrated as crosses in fig. 5. In agreement with the visual assessment of the gravity field, the maximum gradients are greatest in magnitude and best-aligned beneath the Hunton Anticline region (east of CNRA). The South Sulphur and Mill Creek Faults correspond to lineated maximum gradient locations. The Reagan Fault is not as well surveyed by gravity, but a line of maximum gradient positions extends across the portion of the fault that is obscured by the Lake of the Arbuckles. The Sulphur Fault is associated with small gravity gradients and does not have maximum gradient locations associated with it. West of the Arbuckle-Simpson Aquifer outcrop area, the maximum gradients are lower in magnitude than to the east.

For the faults marked by maximum gradient alignments, a comparison of the outcrop location of the fault and the maximum gradient locations can provide a first-order indication of fault-dip. If the fault is vertical, then the maximum gravity gradients are centered on the fault trace. If the fault dips and if the density contrast across the fault increases with depth, then the maximum gradient locations are displaced in the direction of the dip. Thus, the Mill Creek Fault Zone appears to be largely vertical, given the close spatial correspondence of maximum gradients and fault trace (fig. 5). The South Sulphur Fault appears to be north-dipping and to have a greater density contrast with depth, given the 500 to $800 \mathrm{~m}$ offset of the maximum gradients to the northeast of the fault trace. The Reagan Fault, although poorly surveyed by gravity and obscured by the Lake of the Arbuckles, appears to be south-dipping in a number of places. A northern dip to the South Sulphur Fault is consistent with normal fault displacement at the southern edge of the structural Sulphur Syncline, and a southern dip to the Reagan Fault is consistent with a reverse component of motion, in agreement with interpretation from geological mapping (Denison, 1982).

In a complementary approach, we constructed two-dimensional models of subsurface structures to explain the observed gravity anomalies (fig. 7). Because subsurface well information is sparse beneath the Hunton Anticline and CNRA, these models have been assigned only very simple block geometry. The primarily utility of the models will be to constrain the geometry of the major faults at depth, including fault dip where the faults crop out and the fault positions where they are buried. Densities of the blocks are prescribed based on the average characteristics of the measured rock units: the Arbuckle Group carbonates are assumed to range in density from the Bouguer reduction 
value of $2.67 \mathrm{~g} / \mathrm{cm}^{3}$ to about $2.60 \mathrm{~g} / \mathrm{cm}^{3}$; Simpson Group rocks are assumed to be 0.10 to $0.15 \mathrm{~g} / \mathrm{cm}^{3}$ less than the Bouguer density; and Pennsylvanian rocks are assumed to be $0.20 \mathrm{~g} / \mathrm{cm}^{3}$ less than the Bouguer density. The blocks correspond to the structural synclines and anticlines of the westernmost Hunton Anticline region; their depth extent was arbitrarily set to $1 \mathrm{~km}$ below the land surface. Changes in the depth extent of individual blocks trade-off with the density perturbations required to explain the observed gravity anomalies. One geometric constraint was available: the depth to the base of the Vanoss Formation at three locations within the Travertine District (table 1 and fig. 1c), and this was utilized when constructing the block models. The depth to the base of Vanoss Formation ranges from $37 \mathrm{~m}$ at the East Well in the easternmost part of the district to nearly $100 \mathrm{~m}$ at Vendome Well near the center of the district (table 1).

In the outcrop area of the Arbuckle-Simpson Aquifer, it is straightforward to generate simple block models whose gravity predictions match the observations (figs. 7a, b). The gradients associated with the Sulphur Syncline gravity low require a north-dipping South Sulphur Fault. The modeled dip is steep, $60^{\circ}$, in the profiles at $96^{\circ} 54^{\prime} \mathrm{W}$ and $96^{\circ} 55^{\prime} \mathrm{W}$. Sensitivity tests conducted with forward modeling allow dips within about $15^{\circ}$ of that value. The main strand of the Sulphur Fault has a smaller gravity signature that does not allow constraint of its geometry very well: it may be vertical or relatively steeply dipping $\left(>45^{\circ}\right)$ in either direction. Gravity observations are not available to characterize the Mill Creek Fault in the Arbuckle-Simpson Aquifer outcrop area (figs. 7a, b, c) via twodimensional modeling. Moving west of the Arbuckle-Simpson Aquifer outcrop area (fig. 6), the low-density Sulphur Syncline becomes narrower, and the low densities associated with the Mill Creek Syncline are detected on the profiles at $96^{\circ} 56^{\prime} \mathrm{W}$ and $96^{\circ} 57^{\prime} \mathrm{W}$ (figs. $7 \mathrm{c}, \mathrm{d}$ ). Again, the lack of gravity data south of the Mill Creek Fault does not permit characterization of the fault itself. The southernmost observations of high gravity in these profiles reflect the influence of shallow, high-density basement of the neighboring Tishomingo Anticline, but these effects are not modeled with the sparse data.

The gravity anomaly of the profile at $96^{\circ} 58^{\prime} \mathrm{W}$ (fig. 7e) was difficult to model as a simple extension of its neighbor 1 mile to the east (fig. 7d). To illustrate the change in density structure required between the easternmost modeled profiles and the profile at $96^{\circ} 58^{\prime} \mathrm{W}$, we extrapolated the positions of the major tectonic blocks from the Arbuckle-Simpson Aquifer outcrop profiles along the orientation of the faults. The predicted and observed gravity variations are anti-correlated (fig. 7e, top), emphasizing the change in structure that was inferred from the map-view analysis of the isostatic gravity anomaly.

To test the possibility that the Vanoss Formation obscures gravity signatures from underlying units, we conducted a number of forward modeling tests from which we conclude that the cover of Vanoss Formation $(<100$ $\mathrm{m}$ ) is not thick enough in the eastern Travertine District to mask gravity anomalies arising from underlying units. By artificially raising the elevation of the gravity observations by $100 \mathrm{~m}$, the gravity anomalies from prePennsylvanian rock units observed in the outcrop area are attenuated only minimally $(<5 \%)$. In addition, the Vanoss layer is not thick enough to produce significant gravity anomalies, even if it were heterogeneous with densities spanning a realistic range of values $\left(+/-0.2 \mathrm{~g} / \mathrm{cm}^{3}\right)$. Thus, we conclude that the structural changes in the prePennsylvanian units inferred from gravity in our analysis above are significant and are primarily responsible for the observed gravity anomalies.

For the westernmost profiles at $96^{\circ} 59^{\prime} \mathrm{W}$ (fig. $7 \mathrm{f}$ ) and $97^{\circ} 00^{\prime} \mathrm{W}$ (fig. $7 \mathrm{~g}$ ), we cannot sensibly generate crustal blocks that are simple extensions of the structures modeled to the east. Using a different approach, we consider that the gravity anomalies arise from a different source, namely the interface between relatively lowdensity Paleozoic units and higher-density Precambrian basement rocks. The densities assigned to these units were chosen to be $2.52 \mathrm{~g} / \mathrm{cm}^{3}$ and $2.77 \mathrm{~g} / \mathrm{cm}^{3}\left(-0.15 \mathrm{~g} / \mathrm{cm}^{3}\right.$ and $+0.10 \mathrm{~g} / \mathrm{cm}^{3}$ relative to the Bouguer density), respectively. Using these densities, basement topography was modeled with both steep and gradual gradients and with a maximum relief of about $2.5 \mathrm{~km}$; the fit to the observed gravity anomalies is excellent, as expected by constraining structure only by matching an observed gravity profile. As noted above, the gravity field for these westernmost profiles is not two-dimensional, so the modeled interfaces are only approximate. The steepest and greatest relief occurs at the boundary between the Mill Creek Syncline and the Tishomingo Anticline, consistent with the nearsurface position of Precambrian granites in this portion of the Tishomingo Anticline and with a thickness of Mill Creek Syncline deposits exceeding 8,000 feet (2.4 km) (Ham, 1955). 


\section{Discussion}

\section{Faults beneath Chickasaw National Recreation Area}

The primary goal of this study was to use gravity observations to learn how the major faults of the Arbuckle-Simpson Aquifer outcrop area extend westward beneath CNRA. Like Cates (1989), we do not see a clear, linear projection of these structures beneath CNRA. That said, we argue that gravity observations support the notion of curvilinear projection of the Sulphur Fault and the Mill Creek Fault Zones towards CNRA and, with a change of density configuration, of the linear projection of the South Sulphur Fault across CNRA near the mineral springs of the Travertine District.

Just east of the Travertine District, the NE-SW-oriented gravity contours (fig. 5) suggested to Cates (1989) that the main strand of the Sulphur Fault deviated to the WSW beyond where it is exposed in the Arbuckle-Simpson Aquifer outcrop area. Cates (1989) noted that the observation of Arbuckle Group, rather than Simpson Group, rocks beneath a cover of Vanoss Formation at East Well and West Well (Figures 1c and 6) in the eastern Travertine District supports the conclusion that the Sulphur Syncline, which would juxtapose Simpson Group units beneath Vanoss Formation cover, starts to close off immediately to the west of the Arbuckle-Simpson Aquifer outcrop area. The results of this study confirm these conclusions of Cates (1989). By expanding beyond the study area of Cates (1989) and by utilizing forward modeling methods, this study makes a number of additional conclusions.

First, in a similar manner to the Sulphur Fault, the Mill Creek Fault Zone appears to deviate to the WSW beyond its exposure in the Arbuckle-Simpson Aquifer outcrop area (fig. 5). The Belton Anticline gravity high merges with a gravity high beneath Rock Creek that is perpendicular to the main fault traces. The Mill Creek Syncline is marked by a prominent, oval gravity low that terminates against the Rock Creek gravity high. The Reagan Fault extends linearly across the southern Lake of the Arbuckles, and the inferred extension of the Mill Creek Fault Zone appears to terminate against the Reagan Fault.

Second, a gravity gradient west of Travertine District has the same orientation and is collinear with the gravity gradient that marks the South Sulphur Fault where it is exposed southeast of the Travertine District (fig. 5), suggesting that the two are related and that the South Sulphur Fault extends linearly through the southern Travertine District. A change in polarity of the density contrast across the South Sulphur Fault is required for this interpretation to be viable: west of the Travertine District, denser rocks would be expected to occur north of the South Sulphur Fault extension, opposite of the configuration of less-dense rocks of the Sulphur Syncline juxtaposed against more-dense rocks of the Belton Anticline in the Arbuckle-Simpson Aquifer outcrop area. Such changes in density along a fault are relatively common in strike-slip settings where different rock units are juxtaposed along the fault, but this inference from gravity for the South Sulphur Fault should be substantiated by other geophysical and sampling methods to verify this interpretation.

Third, there is strong evidence supporting a northward dip to the South Sulphur Fault, both from analysis of gravity anomaly amplitude and gradient and from forward models. Given that younger rocks of the Simpson Group to the north of the fault are juxtaposed with older Arbuckle Group rocks to the south, this northward dip supports the interpretation that the Sulphur Syncline is at least in part formed by a structural graben. Whether this graben is the product of simple tectonic extension or whether it formed in the environment of a pull-apart basin in a strike-slip dominated zone is unknown given available geological mapping and gravity interpretations. If the westward extension of the South Sulphur Fault is indeed linear, as inferred above, and if the Sulphur Fault curves and terminates against the South Sulphur Fault, then the Sulphur Syncline occupies a pull-apart setting in a left-stepping, left-lateral fault configuration. The similarity of the inferred western terminations of the Sulphur Fault and the Mill Creek Fault Zones indicates that the Mill Creek Syncline may have a similar tectonic setting to the Sulphur Syncline.

Figure 8 illustrates the inferred extensions of the major faults beneath CNRA within the study area. The precise location of the faults cannot be determined from gravity alone, but any linear extension of the South Sulphur Fault places the fault very close to the locations of Bromide and Mineral Springs in the western Travertine District. The Sulphur Fault appears to deviate to the south of the fresh-water Buffalo and Antelope Springs, but approaches to within about $500 \mathrm{~m}$ of them. The springs in the central Travertine District are $1.5 \mathrm{~km}$ or more from the nearest inferred fault. In the outcrop area, fault traces are mapped with single strands in some instances and multiple 
strands, separated by hundreds of meters, in others (fig. 8), suggesting that the width of deformation varies among the major faults. This, in turn, suggests that the zones about which some faults influence groundwater flow may vary with similar dimensions.

Thus, the mineral springs of the western Travertine District are arguably situated directly above the South Sulphur Fault, while the freshwater springs of the eastern Travertine District may be related to the Sulphur Fault if its deformation occurs across a zone hundreds of meters wide. The springs of the central Travertine District are not particularly close to any of the buried faults inferred from gravity. The location of springs depends not only on the conditions of the underlying aquifer but also on factors such as land elevation, piezometric surface, and properties of the overlying confining layer. A more definitive characterization of the buried faults and of the hydrologic properties of the aquifer and confining layers requires observations to complement the gravity analysis, such as from borehole stratigraphy or other geophysical methods.

\section{Basement variation and gravity anomalies}

The ability to model observed gravity anomalies in the western profiles (fig. 7f, g) by varying Precambrian basement depth suggests that basement may be an important interface for gravity variations throughout the Arbuckle Uplift. The eastern gravity profiles could have contributions from basement topography that were not modeled in fig. 7, suggesting that the block densities and thicknesses would require modification. Structural highs and lows developed by the faults of the Hunton Anticline are expected to be reflected in the basement topography; thus, density variations in the Paleozoic section would be correlated with basement topography, and both sources would contribute to surface gravity anomalies. On the other hand, pre-existing topography of the basement surface (described as "local granite islands that stood in the Late Cambrian sea" by Ham, 1969) might contribute gravity anomalies that are uncorrelated with Paleozoic structures.

The significance of basement topography as a contributor to gravity anomaly in southern Oklahoma is illustrated by the Bouguer gravity anomaly map of Oklahoma (fig. 9). The Arbuckle Uplift and the Wichita Uplift to its west are prominent gravity highs, and the Ouachita Mountains are a significant gravity low. The uplifts are associated with very shallow basement, and the Ouachita fold-belt is associated with a thickened Phanerozoic section, displacing relatively dense basement and mantle materials downwards and leading to the negative gravity anomaly. North of the Wichita Uplift are gravity lows over the Anadarko and Ardmore Basins that have deep basement.

The gravity anomaly patterns for southern Oklahoma suggest that gravity may be a promising proxy for Precambrian basement depth, but a number of factors must be known before one can convert the observed gravity variation into basement depth variation. Primarily, the gravity effects of overlying igneous (restricted to the aulacogen) and sedimentary rocks must be known. Away from the Arbuckle-Simpson Aquifer outcrop area, petroleum exploration has been active, and seismic and borehole observations are available. By constraining gravity-inferred basement depths at discrete sites or profiles, the gravity method can be calibrated and its utility as a quantitative predictor of basement geometry can be evaluated.

\section{Recommendations for future study}

The gravity results presented in this study have constrained the nature of the Sulphur and South Sulphur Faults as they approach CNRA from the east. These faults appear to extend towards the fresh water and mineral springs, respectively, of the Travertine District (fig. 1c), so these faults likely play a role in the location of these springs. Gravity indicates that the Sulphur Syncline is lozenge-shaped, with a northern margin just south of the eastern Travertine District. To provide more definitive images of the subsurface extension of these faults, other geophysical methods are required.

Cates (1989) collected ground magnetic observations at his gravity stations, and he detected significant magnetic anomalies that were associated with some, but not all, of the gravity anomalies near CNRA. Cates (1989) suggested that in the vicinity of the Sulphur Syncline, magnetic highs might arise from accumulation of sediment enriched in magnetic minerals at the base of some of the active fault scarps. His discrete magnetic data do not permit a high-resolution assessment of magnetics as a detector of fault position and character, but it is possible that 
continuous ground magnetics or low-altitude aeromagnetic observations might provide complementary evidence of the faults.

Seismic and electromagnetic methods are sensitive to different physical properties than gravity and magnetics methods, and thus would also provide useful constraints on subsurface structure. Geophysical anomalies would be expected to arise both from lithologic interfaces that are offset across the fault and from damage zones at the fault interface. Under the Vanoss Formation cover beneath CNRA and eastwards to the Arbuckle-Simpson Aquifer outcrop area, these other geophysical techniques would need to penetrate at least tens of meters to detect rocks of the aquifer formations; ideally, they would penetrate several hundreds of meters with sufficient resolution to characterize fault zones and offset strata in the uppermost Arbuckle-Simpson Aquifer units.

Borehole lithologic and geophysical information will also contribute to the understanding of the faulted structures beneath CNRA. An effort is underway to compile water well and oil and gas well information and to generate structural contour and fault maps of the Arbuckle-Simpson Aquifer in the western Hunton Anticline, under the sponsorship of the Arbuckle-Simpson Hydrology Study (J. Puckette, personal comm.). These results will allow the testing and refinement of models based on geophysical analysis. In a broader area, the analysis of deeper oil and gas well information, especially to the west of CNRA, will allow characterization of major crustal structures well beyond the borders of the Arbuckle-Simpson Aquifer outcrop area. Cates (1989) performed this analysis with a subset of the available well data, and a modern synthesis will allow construction of a three-dimensional geological model of the major structures in this area. A USGS/Geology Discipline effort is underway to pursue this goal (C. Blome, personal comm.).

From the perspective of understanding the gravity field in the vicinity of CNRA, additional gravity station data would be very helpful to refine the measured anomalies (fig. 4) associated with the Arbuckle-Simpson Aquifer outcrop area and with the western margin of progressive burial. While most of the Sulphur Syncline is well characterized, additional data to the east of existing coverage would confirm the relative significance of the physical anomalies associated with the Sulphur and South Sulphur Faults, and such coverage would help constrain the nature of their merger just to the east of the study area. Additional gravity observations on either side of the Mill Creek Fault Zone in the Arbuckle-Simpson Aquifer outcrop area would improve our interpretation of this major fault and would help to characterize the Mill Creek Syncline where existing coverage is absent. Also, additional data on either side of the Reagan Fault would refine our interpretation of this as a dipping, thrust structure and would help to constrain the importance of high-density Precambrian basement on the gravity signature of the Tishomingo and southern Hunton Anticlines. More observations north of CNRA would characterize better the gravity field in the area where the Arbuckle-Simpson Aquifer is covered by Pennsylvanian units and would allow an assessment of how basement topography variations might explain observed gravity anomalies.

\section{Acknowledgments}

We thank the National Park Service, Water Resources Division for project funding and Jennifer Back (NPS/WRD Water Rights Branch) for facilitating this research. Support was also received from USGS National Cooperative Geologic Mapping Program project on the geohydrology of the Edwards and southern Trinity aquifers (Charles Blome, Project Chief). We are indebted to Randall Herr, Scott Langford, and Michael Ducre of the Naval Oceanographic Office (NAVOCEANO) for extensive help in installing and trouble-shooting the marine gravimeter during our field sessions, and we thank Daniel Fornari (WHOI) for facilitating our use of the NAVOCEANO gravimeter. Scott Christenson (USGS, Oklahoma City) provided the differential GPS system, and he assisted our field operations in many ways. Maurice Tivey (WHOI) provided the electronic compass. Kendall Truett, Darryl Carter, Steven Burrough, and Sue Braumiller (CNRA) provided assistance throughout the fieldwork. Noel Osborn (OWRB) and other investigators of the Arbuckle-Simpson Hydrology Study provided data and advice at all stages of this work. Jeremy Lui (USGS) conducted lab measurements, and Don Plouff (USGS) provided programming support. This report was improved by reviews of Neil Suneson (OGS) and Robert Jachens (USGS). 
Table 1. Depth to base of Vanoss Formation (and top of Arbuckle Group) rocks in three wells in CNRA

[Based on Irwin (1972), Hanson and Cates (1994), and Nord (1996); Datums: latitude and longitude, NAD27; elevations, NGVD29]

\begin{tabular}{cccccc}
\hline Well name & Year drilled & Latitude & Longitude & $\begin{array}{c}\text { Surface } \\
\text { elevation (m) }\end{array}$ & $\begin{array}{c}\text { Depth to base of } \\
\text { Vanoss Formation (m) }\end{array}$ \\
\hline East Well & 1972 & $34^{\circ} 30.28^{\prime} \mathrm{N}$ & $96^{\circ} 56.25^{\prime} \mathrm{W}$ & 348 & 37 \\
West Well & 1972 & $34^{\circ} 30.37^{\prime} \mathrm{N}$ & $96^{\circ} 56.95^{\prime} \mathrm{W}$ & 329 & 46 \\
Vendome & $1997^{1}$ & $34^{\circ} 30.33^{\prime} \mathrm{N}$ & $96^{\circ} 58.38^{\prime} \mathrm{W}$ & 288 & 99 \\
\hline
\end{tabular}

${ }^{1}$ most recently drilled hole

Table 2. Physical properties of rock samples grouped by stratigraphic unit

[Properties are averages except for the column containing the range of saturated bulk density]

\begin{tabular}{|c|c|c|c|c|c|}
\hline Stratigraphic grouping & $\begin{array}{c}\text { Number of } \\
\text { samples }\end{array}$ & $\begin{array}{l}\text { Saturated bulk } \\
\text { density }\left(\mathrm{g} / \mathrm{cm}^{3}\right)\end{array}$ & $\begin{array}{c}\text { Saturated bulk } \\
\text { density range }\left(\mathrm{g} / \mathrm{cm}^{3}\right)\end{array}$ & $\begin{array}{c}\text { Porosity } \\
(\%)\end{array}$ & $\begin{array}{c}\text { Susceptibility } \\
\left(10^{-3} \mathrm{SI}\right)\end{array}$ \\
\hline Vanoss Formation & 5 & 2.44 & $2.24-2.59$ & 7 & 0.02 \\
\hline $\begin{array}{l}\text { Sycamore Ls./Weldon } \\
\text { Ls./Woodford Shale }\end{array}$ & 2 & 2.52 & $2.45-2.59$ & 3 & 0.01 \\
\hline Hunton Group & 1 & 2.57 & $2.57-2.57$ & 4 & 0.01 \\
\hline Sylvan Shale/Viola Group & 2 & 2.66 & $2.66-2.66$ & 0.7 & 0.02 \\
\hline Simpson Group & 6 & 2.48 & $2.26-2.66$ & 5 & 0.02 \\
\hline Arbuckle Group & 10 & 2.67 & $2.55-2.80$ & 4 & 0.03 \\
\hline Precambrian granite & 4 & 2.66 & $2.58-2.82$ & 1 & 8.5 \\
\hline
\end{tabular}

Table 3. Gravity base stations used for data collected in 2004 and 2005

[Datums: latitude and longitude, NAD27; elevations, NGVD29; gravity values, IGSN71]

\begin{tabular}{cccccc}
\hline Base name & Latitude & Longitude & Elevation (m) & $\begin{array}{c}\text { Observed gravity } \\
\text { (mGal) }\end{array}$ & Description \\
\hline COALGATE ${ }^{1}$ & $34^{\circ} 32.23^{\prime} \mathrm{N}$ & $96^{\circ} 13.11^{\prime} \mathrm{W}$ & 185.9 & $979,626.22$ & $\begin{array}{c}\text { Coalgate, Okla. Fire } \\
\text { Station (codes ACIC } \\
3841-2 \text {; IGB 11846B) }\end{array}$ \\
& & & & & \\
VENDOME & $34^{\circ} 30.348^{\prime} \mathrm{N}$ & $96^{\circ} 58.378^{\prime} \mathrm{W}$ & 288.4 & $979,648.02$ & $\begin{array}{c}\text { Vendome Well, } \\
\text { CNRA, Okla. }\end{array}$ \\
& & & & & Parking lot of \\
PVENDOME & $34^{\circ} 30.346^{\prime} \mathrm{N}$ & $96^{\circ} 58.353^{\prime} \mathrm{W}$ & 287.8 & $979,648.11$ & $\begin{array}{c}\text { Vendome Well, } \\
\text { CNRA, Okla. }\end{array}$ \\
& & & & & $\begin{array}{c}\text { Rock Creek } \\
\text { RCC12 }\end{array}$ \\
& $34^{\circ} 29.865^{\prime} \mathrm{N}$ & $96^{\circ} 59.211^{\prime} \mathrm{W}$ & 284.3 & $979,647.26$ & $\begin{array}{c}\text { Campground, Site 12, } \\
\text { CNRA, Okla. }\end{array}$ \\
\hline
\end{tabular}

${ }^{1}$ Part of the World Reference Gravity Network (Jablonski, 1974). 


\section{Literature Cited}

Barthel, C. J. J., 1985, Hydrogeologic investigation of artesian springs flow, Sulphur, Oklahoma area: Norman, Okla., University of Oklahoma, M.S. Thesis, 234 p.

Bell, R.E., and A.B. Watts, 1986, Evaluation of the BGM-3 sea gravity meter system onboard R/V Conrad: Geophysics, v. 51, p. 14801493.

Blakely, R.J., 1996, Potential theory in gravity and magnetic applications: Cambridge University Press, 441 p.

Blakely, R.J., and Simpson, R.W., 1986, Approximating edges of source bodies from magnetic or gravity anomalies: Geophysics, v. 51, p. 1494-1498.

Brown, W. G., 1984, Washita Valley fault system—a new look at an old fault: Technical Proceedings of the 1981 Midcontinent Section Meeting of the American Association of Petroleum Geologists, p. 68-80.

Brown, R. L., and G. D. Morgan, 1991, Aulacogen collapse- a model for the compressive stage of aulacogen evolution: Norman, Okla., Oklahoma Geological Survey Circular 92, p. 185-188.

Cates, S. W., 1989, Fault distribution in the Sulphur, Oklahoma area based on gravity, magnetic and structural data: Norman, Okla., University of Oklahoma, M.S. Thesis, $106 \mathrm{p}$.

Cederstrand, J.R., 1996, Digital geologic map of Ardmore-Sherman quadrangles, south-central Oklahoma: U.S. Geological Survey Open-File Report 96-370.

Denison, R. E., 1973, Basement rocks in the Arbuckle Mountains, Regional Geology of the Arbuckle Mountains: Norman, Okla., Oklahoma Geological Survey Special Publication 73-3, p. 43-49.

Denison, R. E., 1982, Geologic cross section from the Arbuckle Mountains to the Muenster arch, southern Oklahoma and Texas: Geological Society of America Map and Chart Series MC-28 R, 8 p.

Fairchild, R. W., R. L. Hanson, and R. E. Davis, 1990, Hydrology of the Arbuckle Mountains area, south-central Oklahoma: Norman, Okla., Oklahoma Geological Survey Circular 91, 112 p.

Goemaat, R., and C. Willard, 1983, Ground-water records for the area surrounding the Chickasaw National Recreational Area, Murray County, Oklahoma: U.S. Geological Survey Open-File Report, 8 p.

Gould, C. N., 1906, Platt National Park: Letter of August, 1906, to honorable B.A. Hitchcock, Secretary of Interior, Washington, D.C., $11 \mathrm{p}$.

Gould, C. N., and S. L. Schoff, 1939, Geological report on water conditions at Platt National Park, Oklahoma: Oklahoma Geological Survey and National Park Service Report no. 249, Open-File Report 39-14, 38 p.

Ham, W. E., 1950, Geology and petrology of the Arbuckle limestone in the southern Arbuckle Mountains, Oklahoma: New Haven, Conn., Yale University, Ph.D dissertation, 162 p.

Ham, W. E., 1955, Field conference on geology of the Arbuckle Mountain region, Part 1-Geology of the Arbuckle and Timbered Hills Groups, Part 2-Regional stratigraphy and structure of the Arbuckle Mountain region: Norman, Okla., Oklahoma Geological Survey Guide Book 3, 61 p.

Ham, W. E., 1969, Regional geology of the Arbuckle Mountains, Oklahoma: Norman, Okla., Oklahoma Geological Survey Guidebook $17,52 \mathrm{p}$.

Ham, W.E., McKinley, M.E., and others, 1954, Geologic map and sections of the Arbuckle Mountains, Oklahoma: Oklahoma Geological Survey Miscellaneous Map A-2, scale 1:72,000.

Ham, W. E., R. E. Denison, and C. A. Merritt, 1964, Basement rocks and structural evolution of southern Oklahoma: Norman, Okla., Oklahoma Geological Survey Bulletin 95, $302 \mathrm{p}$.

Hart, D. L. J., 1974, Reconnaissance of the Water Resources of the Ardmore and Sherman Quadrangles, Southern Oklahoma: Oklahoma Geological Survey Hydrologic Atlas HA-3, scale 1:250,000.

Hanson, R. L., and S. W. Cates, 1994, Hydrogeology of the Chickasaw National Recreation Area, Murray County, Oklahoma: U.S. Geological Survey Water-Resources Investigations Report 94-4102, 86 p.

Hoffman, P.F., Dewey, J.F., and Burke, K., 1974, Aulacogens and their genetic relations to geosynclines, with a Proterozoic example from Great Slave Lake, Canada, in Dott, R.H. and Shaver R.H. eds, Modern and ancient geosynclinal sedimentation: Society of Economic Paleontologists and Mineralogists Special Publication 19, p. 38-55.

Irwin, J.H., 1972, Letter to G. Moore, National Park Service, re. Platt National Park, dated November 6, 1972.

Jablonski, H. M., 1974, World relative gravity reference network North America, Parts 1 and 2: U.S. Defense Mapping Agency Aerospace Center Reference Publication no. 25, originally published 1970, revised 1974, with supplement of IGSN 71 gravity datum values, $1261 \mathrm{p}$.

Johnson, G.R., and Olhoeft, G.R., 1984, Density of rocks and minerals, in Carmichael, R.S., ed., CRC Handbook of Physical Properties of Rocks, Vol. 3: Boca Raton, Fla., CRC Press, Inc., p. 1-38.

Johnson, K.S., 1990, Geologic map and sections of the Arbuckle Mountains, Oklahoma, revision of Ham, W.E., McKinley, M.E., and others, 1954: Norman, Okla., Oklahoma Geological Survey Circular 91, scale 1:100,000. 
Nord, J. D., 1996, Geologic and hydrologic controls on flow at Vendome Well, Sulphur, OK: Stillwater, Okla., Oklahoma State University, M.S. Thesis, 147 p.

Oklahoma Water Resources Board, 2003, The Arbuckle-Simpson hydrology study-Management and protection of an Oklahoma water resource: Oklahoma Water Resources Board Fact Sheet, 4 p.

Plouff, D., 1977, Preliminary documentation for a FORTRAN program to compute gravity terrain corrections based on topography digitized on a geographic grid: U.S. Geological Survey Open-File Report 77-535, $45 \mathrm{p}$.

Schornick, H. M., J. F. Harp, and J.G. Laguros, 1976, Subsurface and surface water flows at Platt National Park, Sulphur, Oklahoma: Norman, Okla., School of Civil Engineering and Environmental Science, University of Oklahoma, $49 \mathrm{p}$.

Simpson, R.W., Jachens, R.C., Blakely, R.J., and Saltus, R.W., 1986, A new isostatic residual gravity map of the conterminous United States with a discussion on the significance of isostatic residual anomalies: Journal of Geophysical Research, $\mathrm{v}$. 91, p. 8348-8372.

Taff, J. A., 1904, Preliminary report on the geology of the Arbuckle Mountains in Indian Territory and Oklahoma: U.S. Geological Survey Professional Paper 31, $97 \mathrm{p}$.

Taff, J. A., 1928, Preliminary report on the geology of the Arbuckle and Wichita Mountains in Indian Territory and Oklahoma: Norman, Okla., Oklahoma Geological Survey Bulletin 12, $95 \mathrm{p}$.

Talwani, M., Worzek, J.L, and Landisman, M., 1959, Rapid gravity computations for two-dimensional bodies with application to the Mendocino submarine fracture zone: Journal of Geophysical Research, v. 64, p. 49-59.

Tanner, J.H., III, 1967, Wrench fault movements along Washita Valley Fault, Arbuckle Mountains area, Oklahoma: American Association of Petroleum Geologists Bulletin, v. 51, p. 126-141.

Tapp, B., 1995, Inversion model for the structural styles in the Southern Midcontinent, 1992 Symposium: Norman, Okla., Oklahoma Geological Survey Circular 97, p. 113-118. 


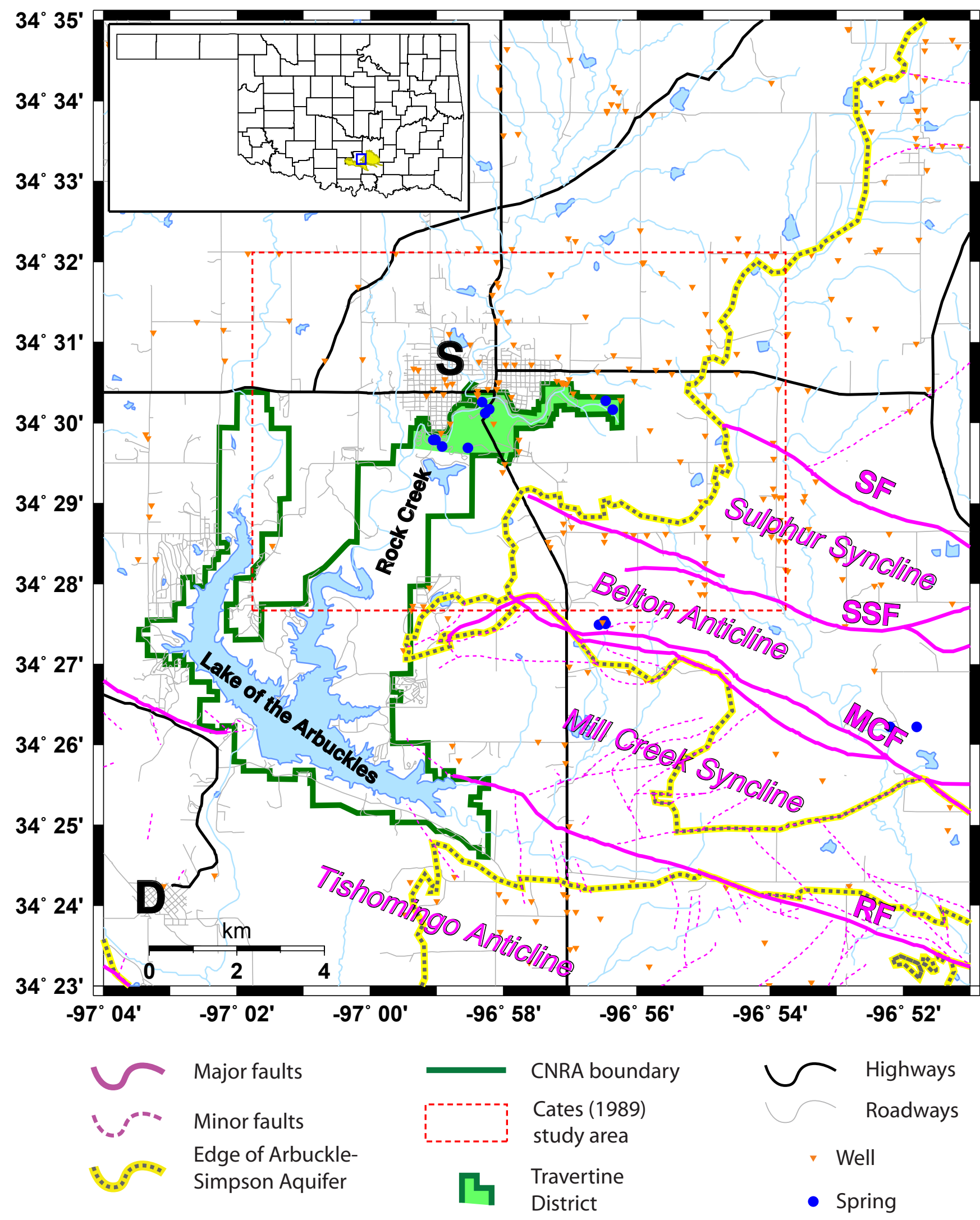

Figure 1. 1a) Index map of the study area. S=City of Sulphur; D=Town of Dougherty; SF=Sulphur Fault; SSF=South Sulphur Fault; MCF=Mill Creek Fault; RF=Reagan Fault. Inset shows our study area (blue box) within the State of Oklahoma; outcrop area of Arbuckle-Simpson Aquifer is shown in yellow. 


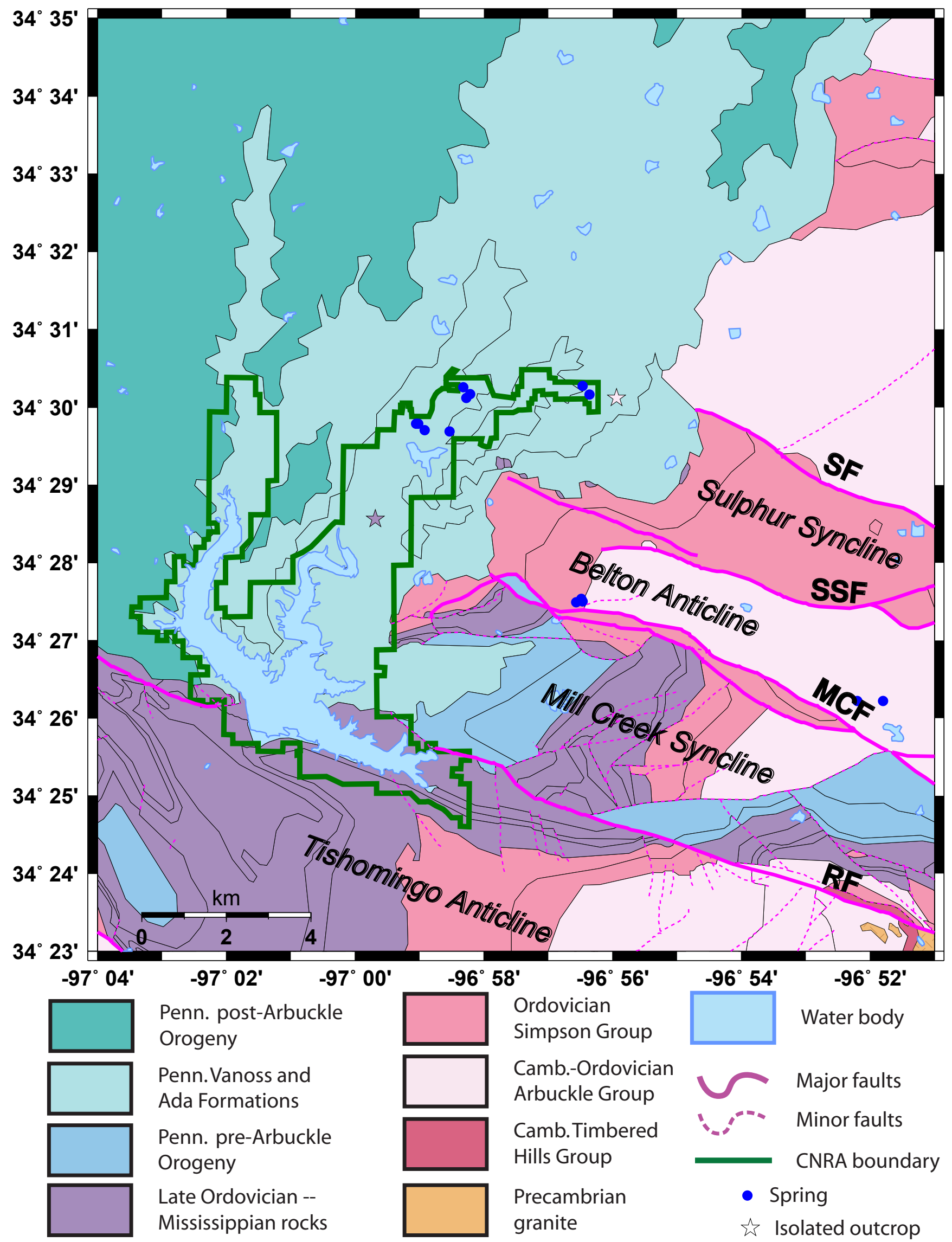

Figure 1 (continued). 1b) Bedrock geology and faults of the study area, based on by mapping of Ham and others (1954), transcribed by Hart (1974), and digitized by Cederstrand (1996) with edits by the Oklahoma Water Resources Board (2004, personal commun.). Two filled stars mark the locations from Cates (1989) of isolated outcrops of uppermost Ordovician Viola Limestone along Rock Creek and of Arbuckle Group units just east of the Travertine District. 


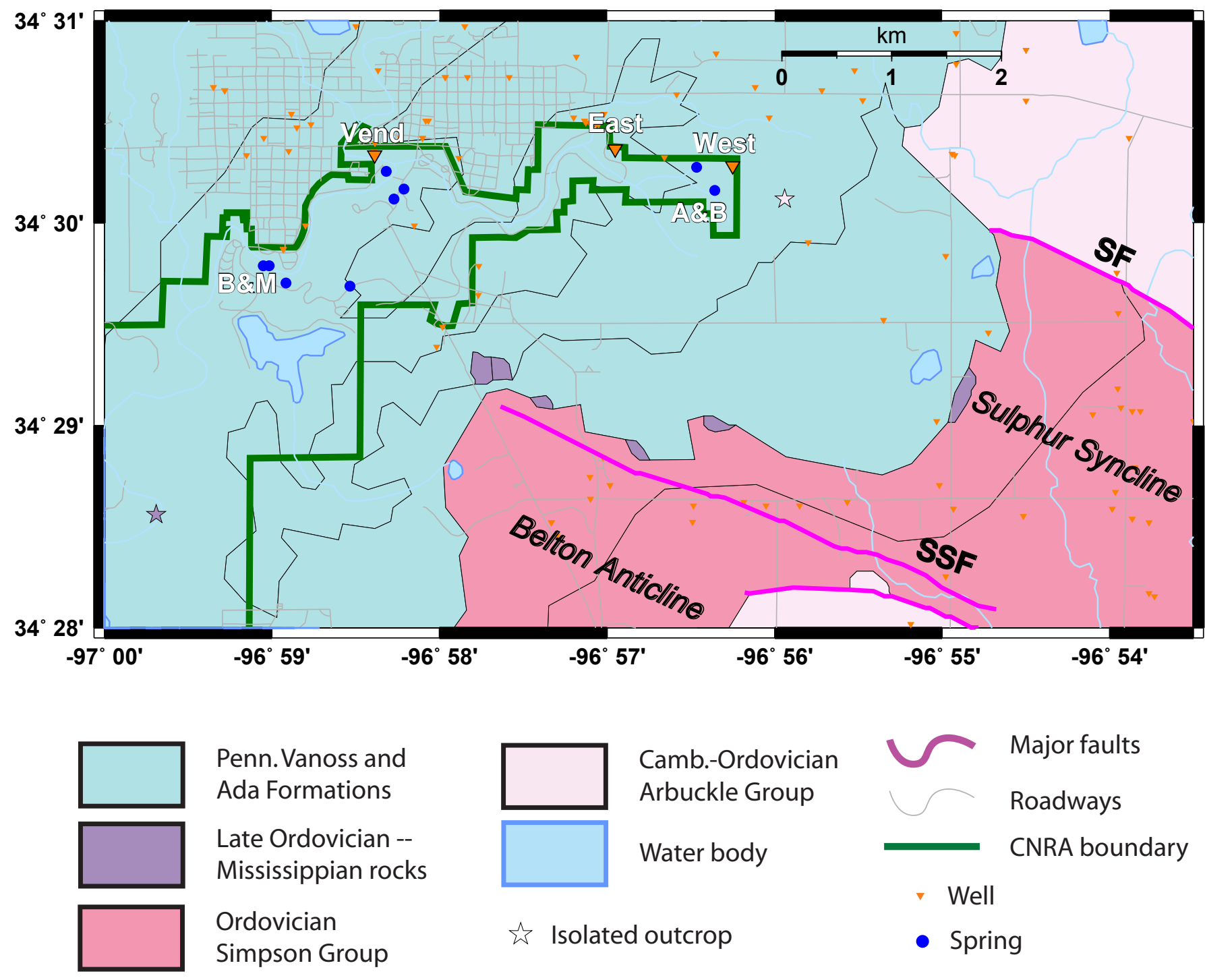

Figure 1 (continued). 1c) Geology of the Travertine District and vicinity, highlighting the locations of three wells and springs and the termination of the SF and SSF traces at the western edge of Arbuckle-Simpson outcrop. East=East Well; West=West Well; Vend=Vendome Well; $A \& B=$ Antelope and Buffalo Springs; B\&M=Bromide and Mineral Springs. 


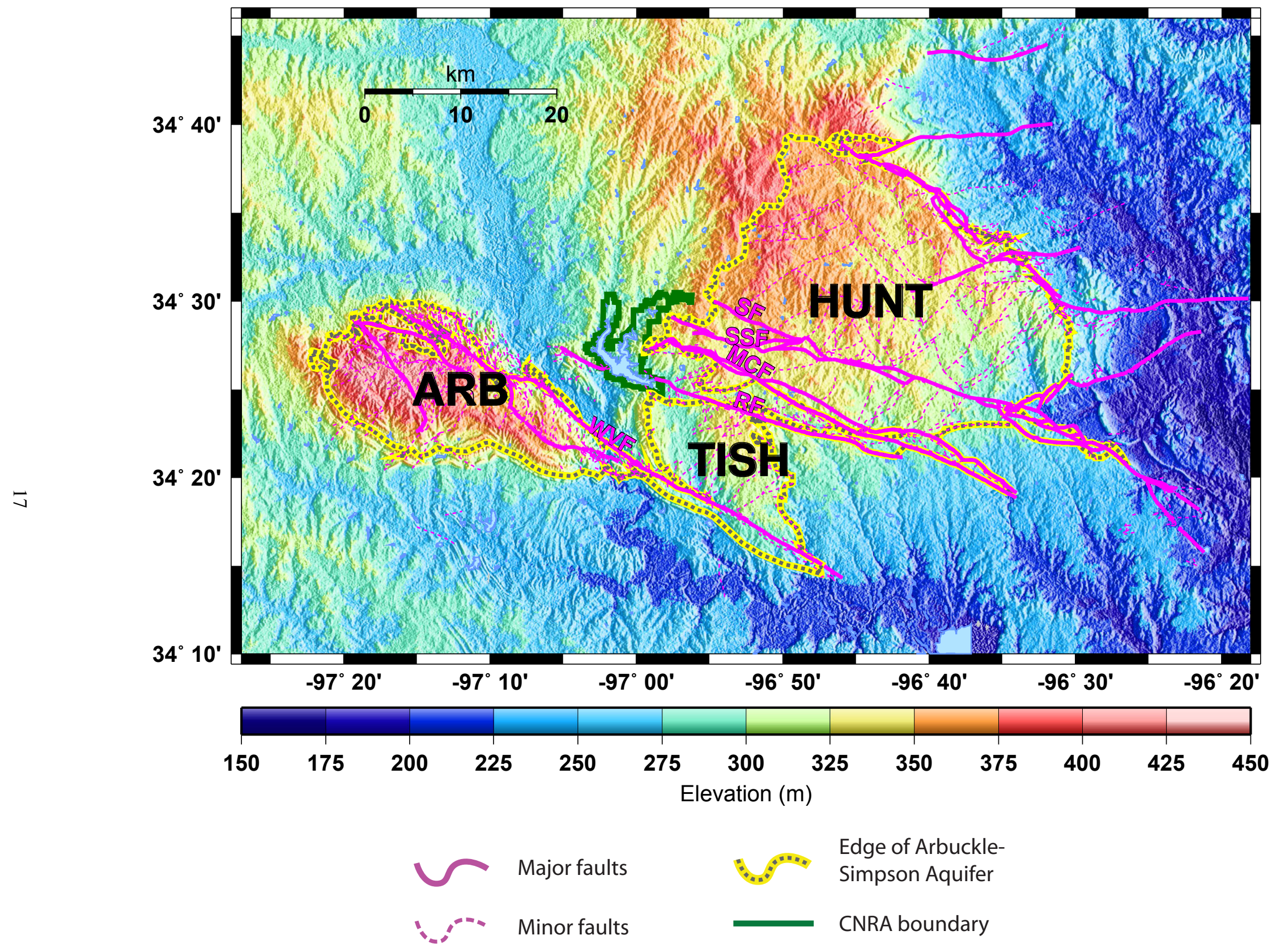

Figure 2. 2a) Topographic map of the Arbuckle Uplift. The Arbuckle, Tishomingo, and Hunton Anticlines are designated by ARB, TISH, and HUNT, respectively. SF=Sulphur Fault; SSF=South Sulphur Fault; MCF=Mill Creek Fault; RF=Reagan Fault; WVF=Washita Valley Fault. 


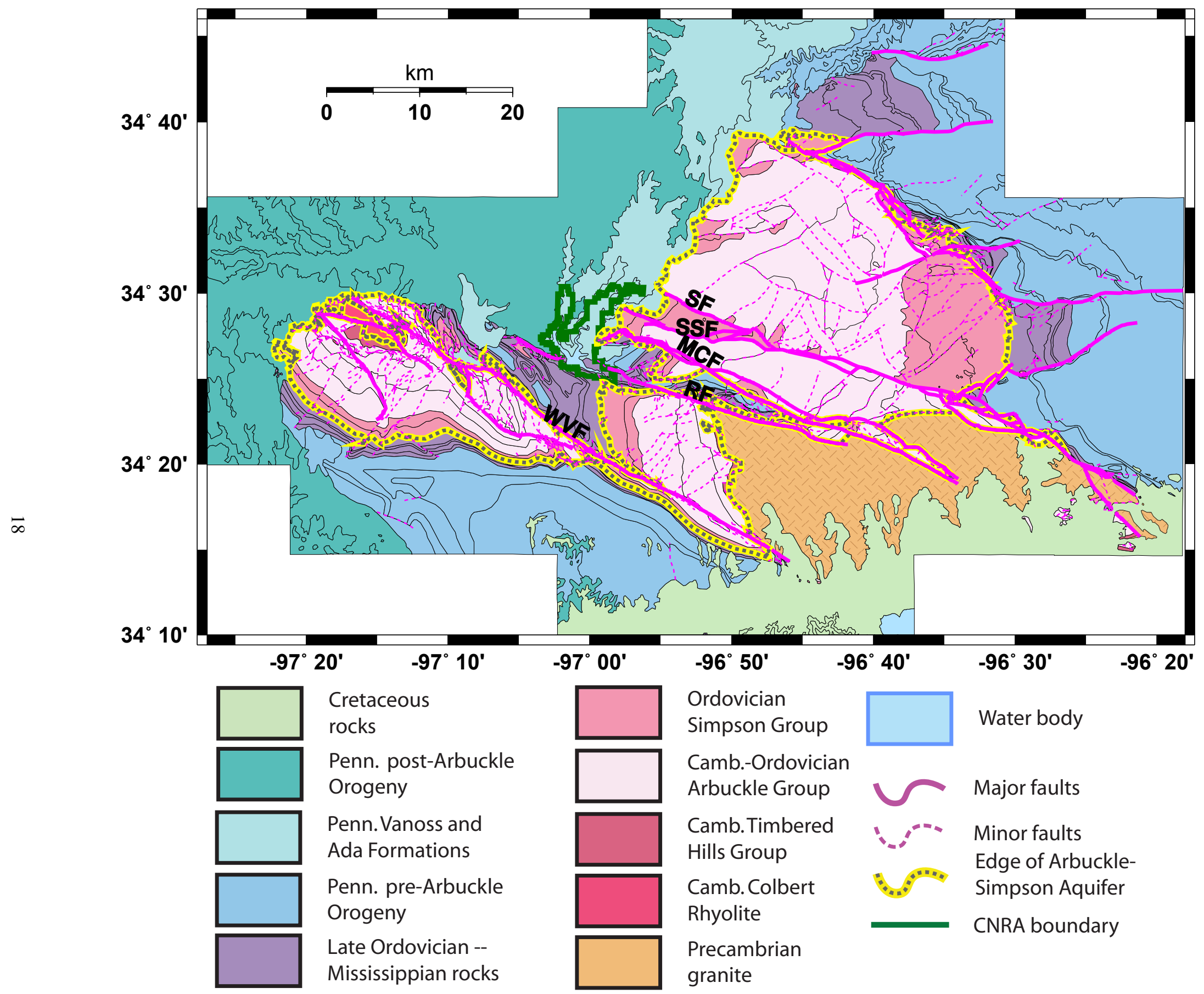

Figure 2 (continued). 2b) Bedrock geology and faults of the Arbuckle Uplift are based on mapping of Ham and others (1954), transcribed by Hart (1974), and digitized by Cederstrand (1996) with edits by the Oklahoma Water Resources Board (2004, personal commun.). 


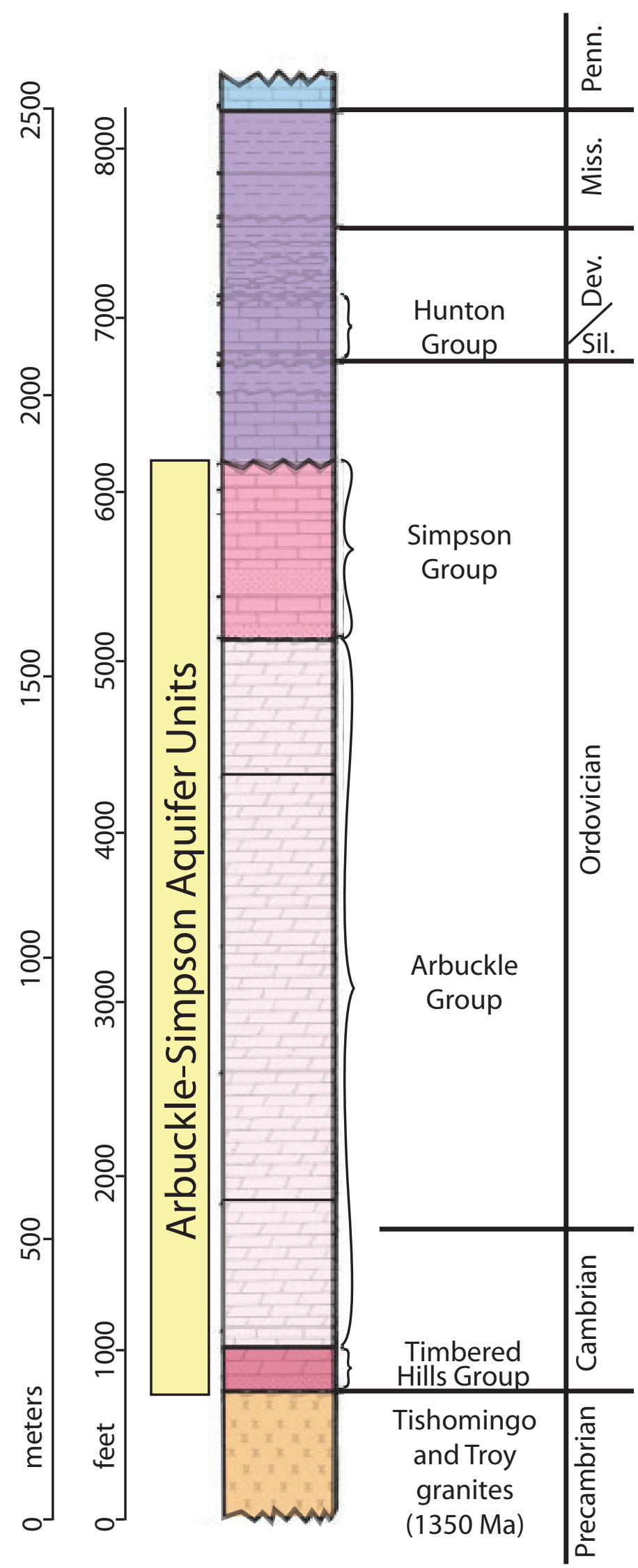

Figure 3. Stratigraphic section of Precambrian and Paleozoic units in the Hunton Anticline area, adapted from Ham (1969). 


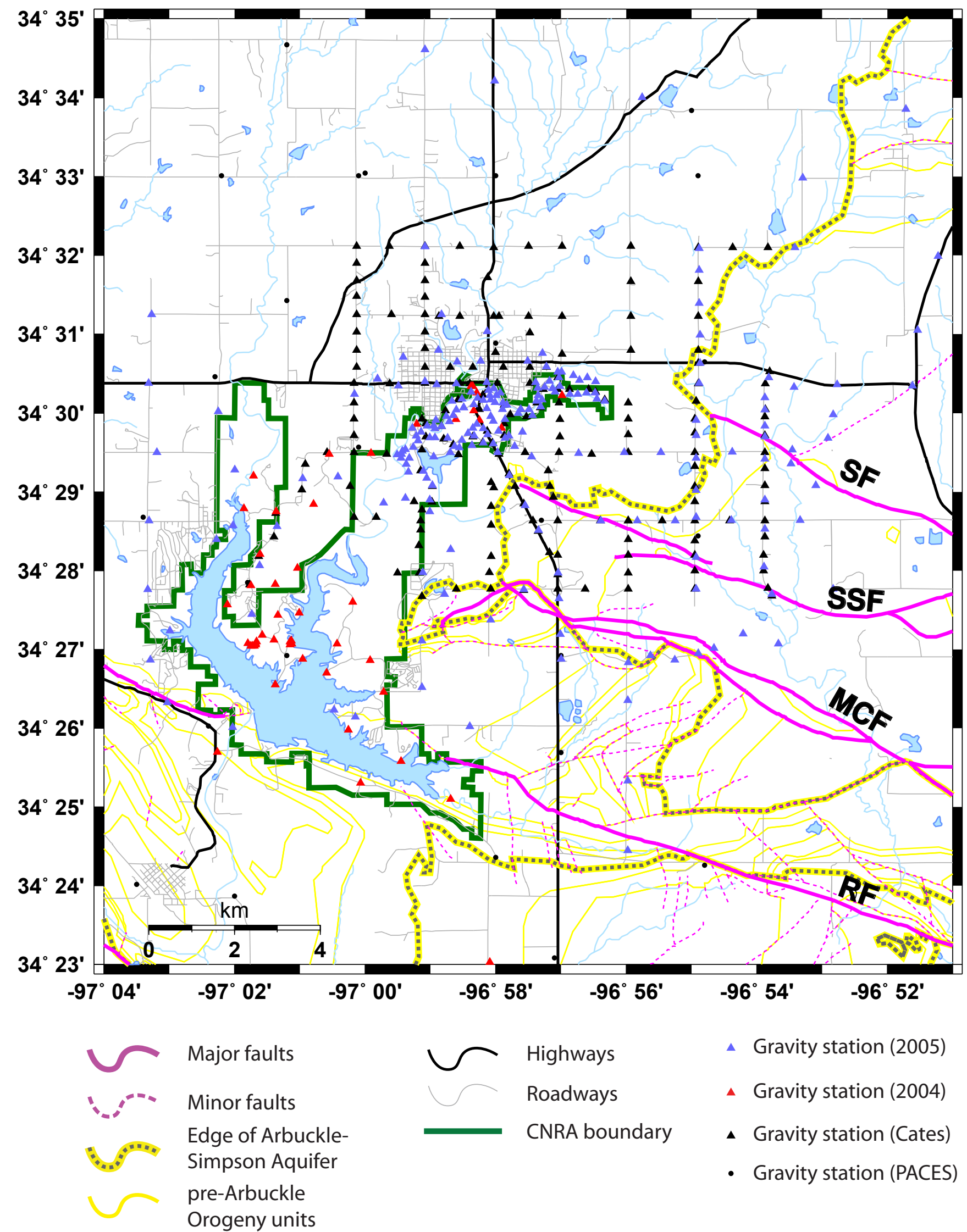

Figure 4. Gravity stations of the study area, with geological features outlined. Fault abbreviations as in fig. 1. 


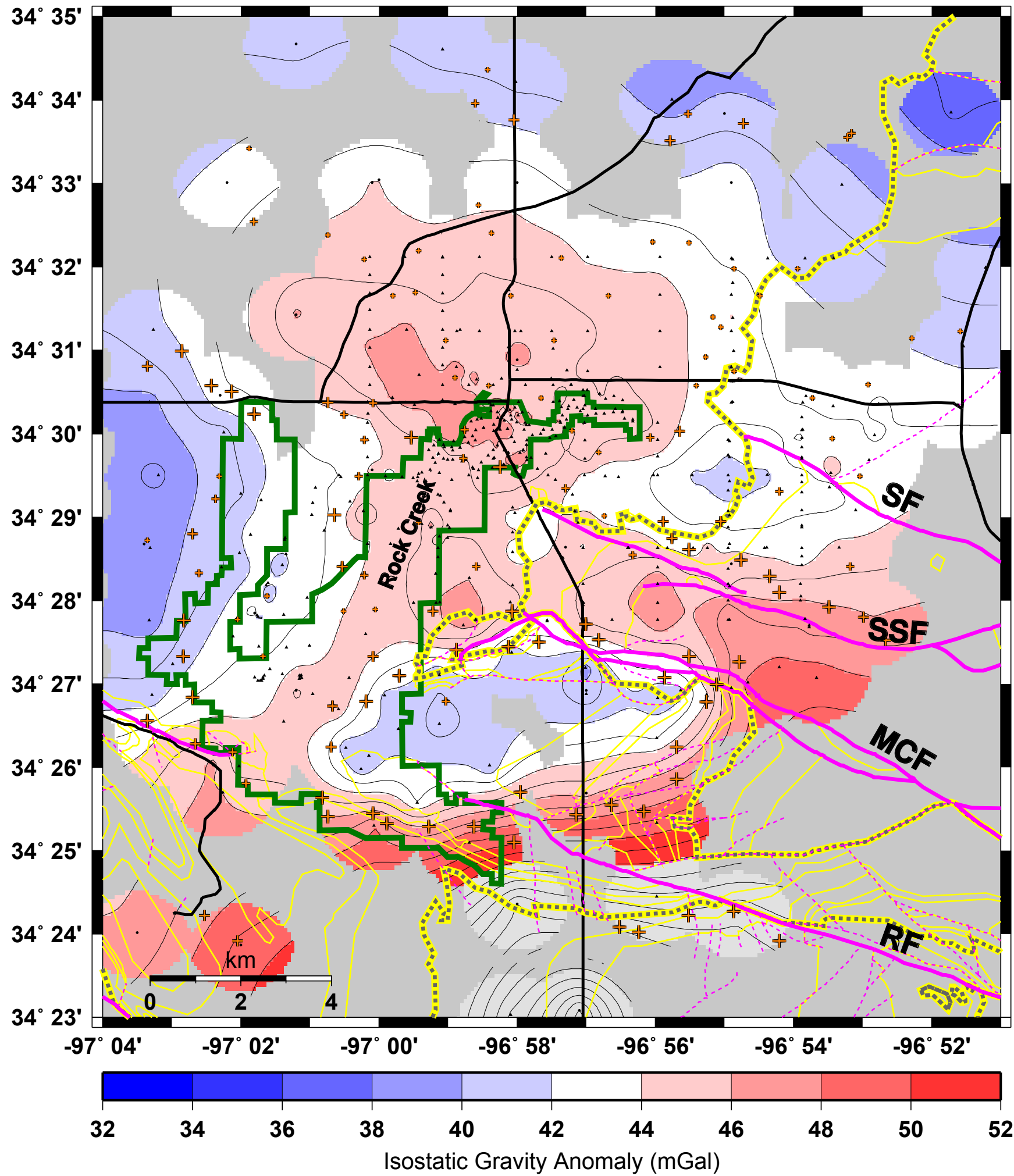

$\begin{array}{lll}\text { Major faults } & \begin{array}{l}\text { Edge of Arbuckle- } \\ \text { Simpson Aquifer } \\ \text { pre-Arbuckle } \\ \text { Orogeny units }\end{array} & \text { CNRA boundary }\end{array}$

Figure 5. Isostatic gravity anomaly map of the study area, contoured every $1 \mathrm{mGal}$, based on a $100 \mathrm{~m}$-spaced grid. Grid locations more than $1.2 \mathrm{~km}$ from the nearest gravity station are assigned a void value (gray shade). Orange crosses denote locations of maximum horizontal gravity gradients, with sizes varying as to whether the magnitude of the gradient falls within the lower, middle, or upper thirds of the distribution. Fault abbreviations as in fig. 1. 


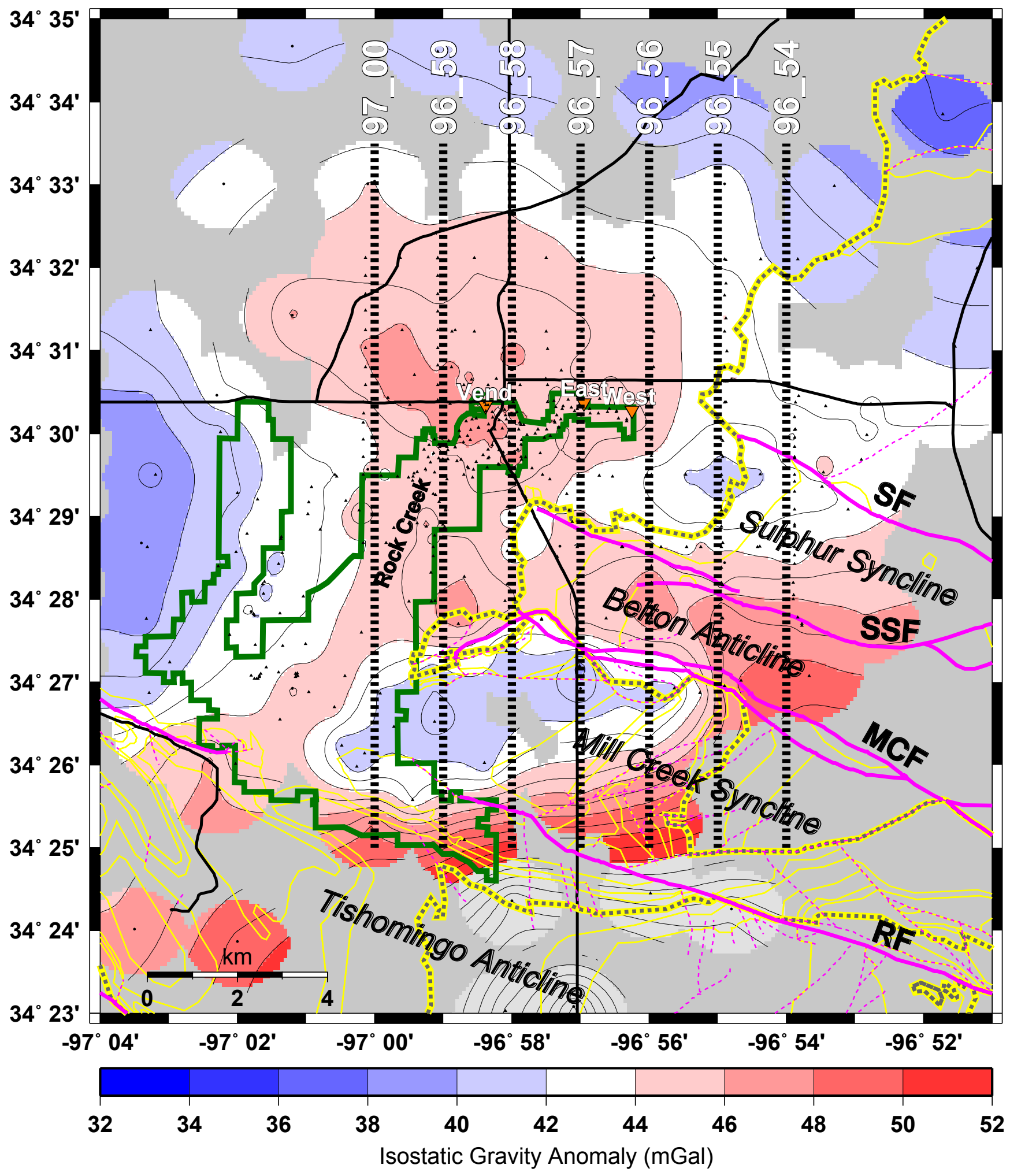

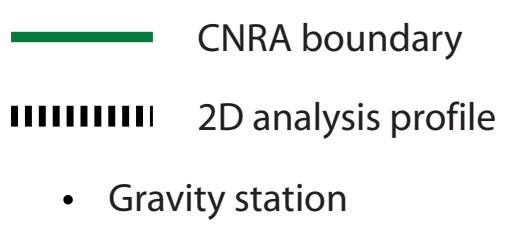

Figure 6. Isostatic gravity anomaly map of the study area with the locations of 7 profiles for two-dimensional analysis superimposed as hachured lines. Fault and water well abbreviations as in fig. 1. 

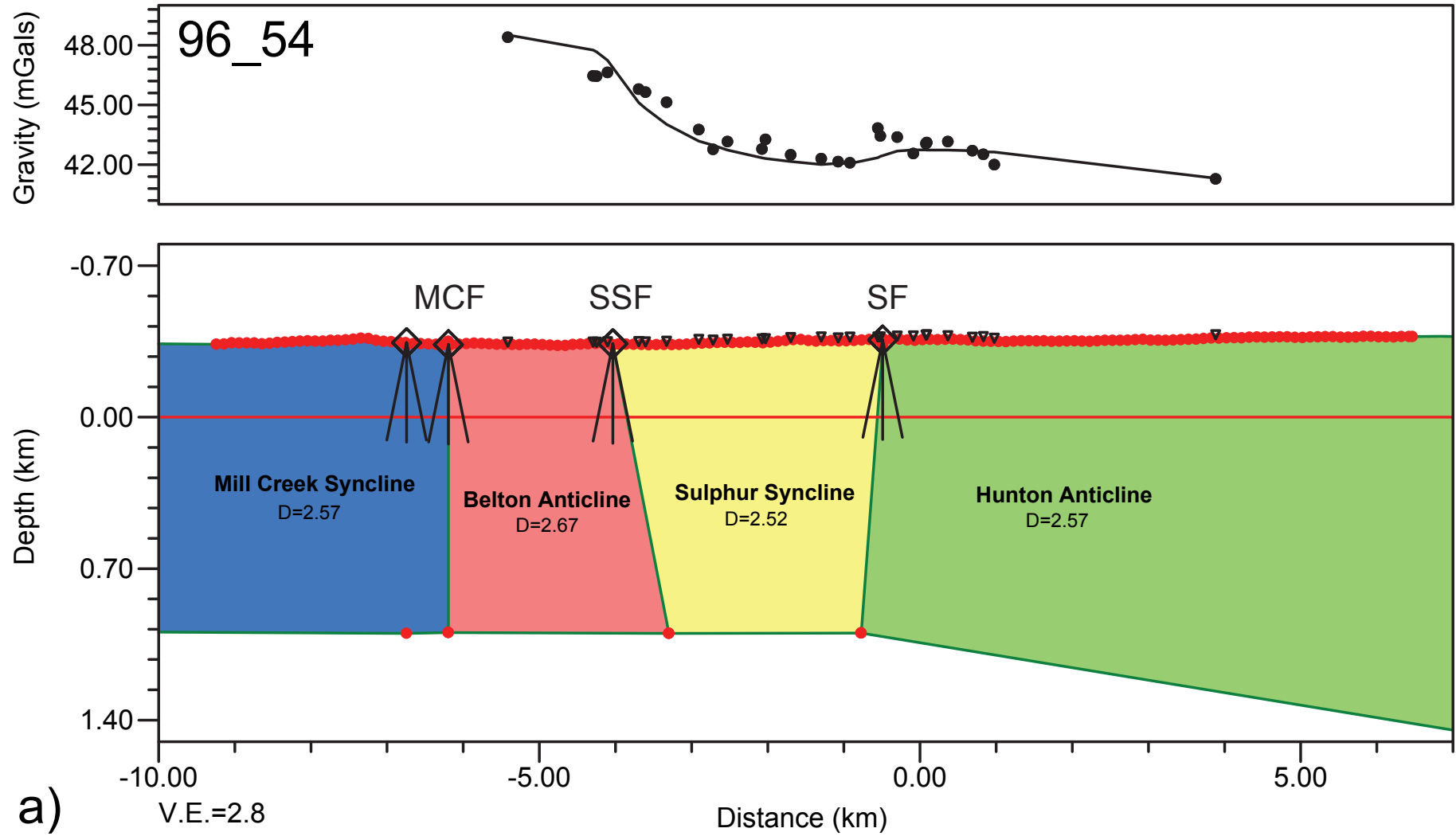

South

North
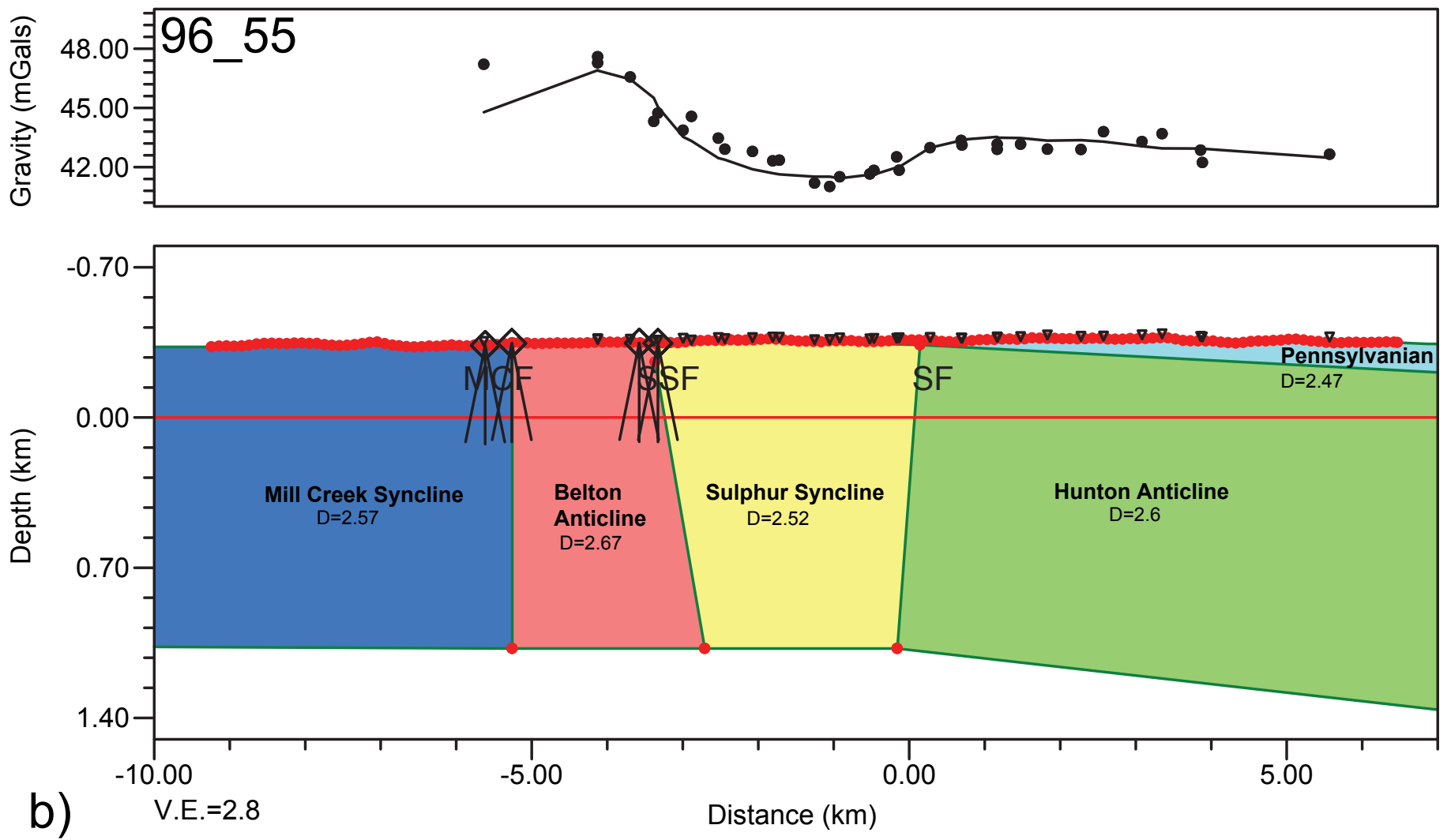

Figure 7. Two-dimensional gravity models along north-south profiles at: 7 a) $\left.96^{\circ} 54^{\prime} \mathrm{W}, 7 \mathrm{~b}\right) 96^{\circ} 55^{\prime} \mathrm{W}$. For each model, the top panel displays gravity observations (filled circles) and modeled gravity (line); the bottom panel shows a cross-section with annotated crustal density blocks. Where faults crop out, symbols are superimposed that illustrate dips of vertical and $60^{\circ}$ to the south and north; multiple strands of the fault systems are shown with separate symbols. Fault abbreviations are as in fig. 1, and densities are listed in $\mathrm{g} / \mathrm{cm}^{3}$. 

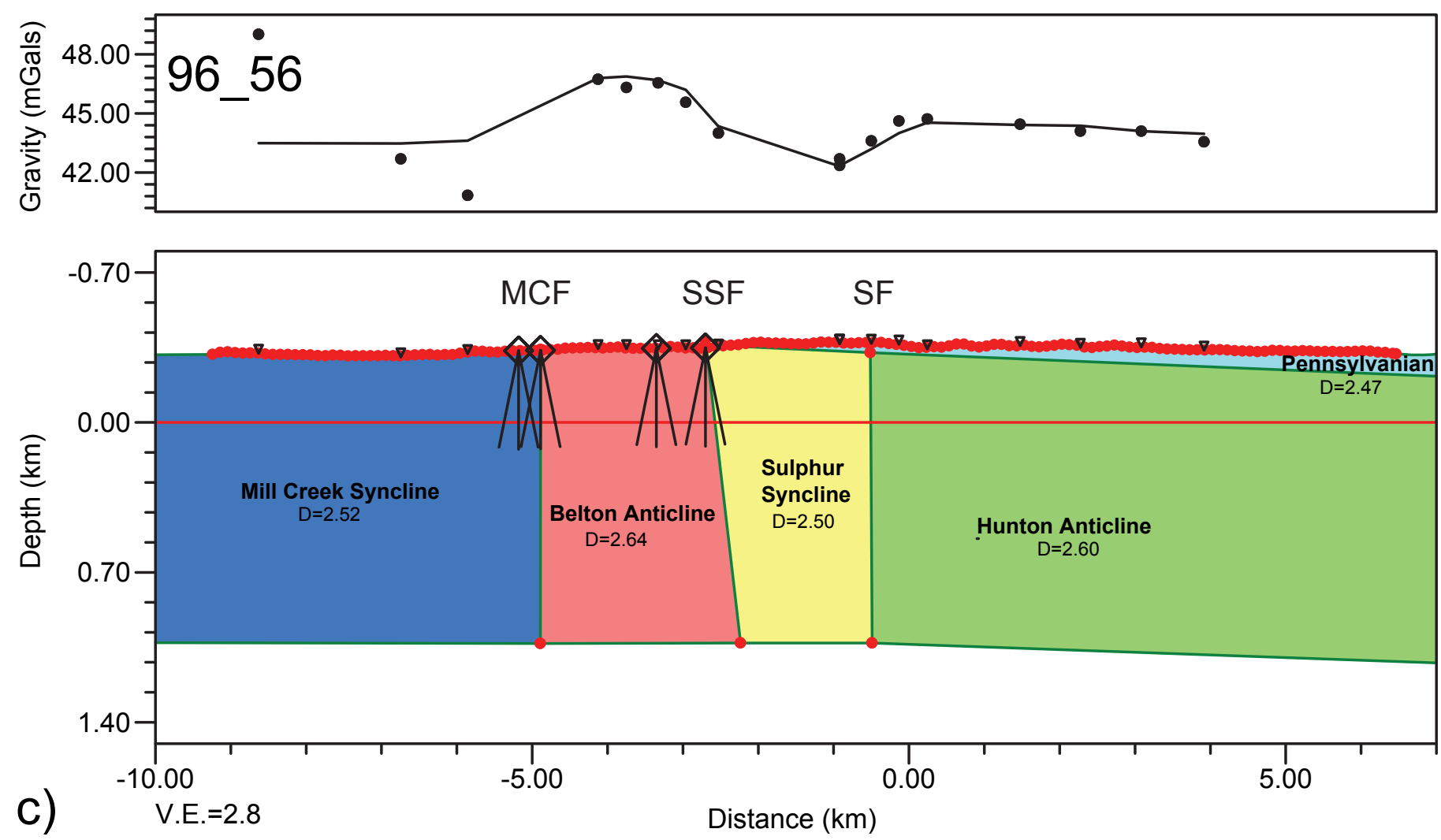

South

North
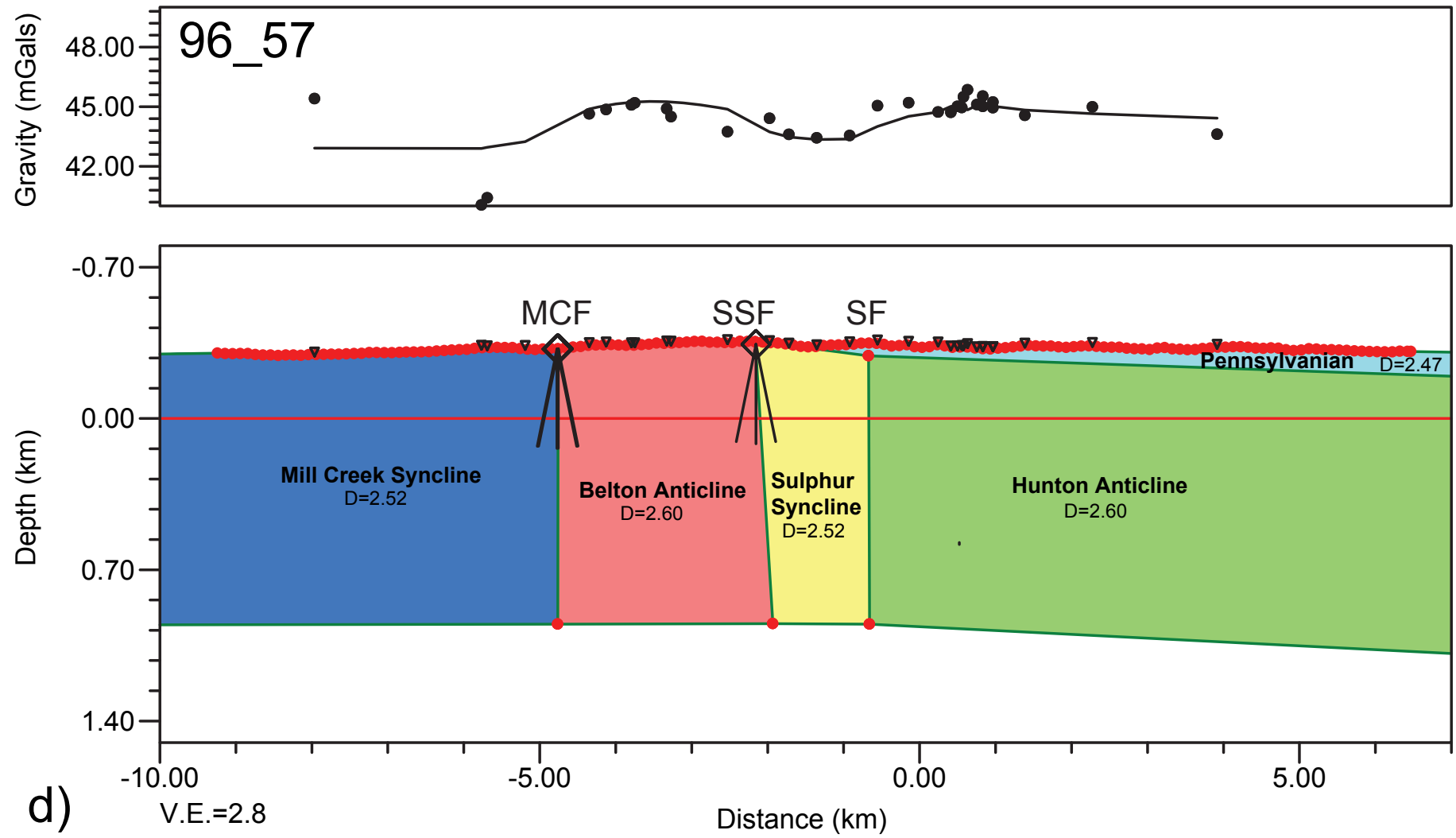

Figure 7 (continued). Two-dimensional gravity models along north-south profiles at: c) $96^{\circ} 56^{\prime} \mathrm{W}$, d) $96^{\circ} 57^{\prime} \mathrm{W}$. 

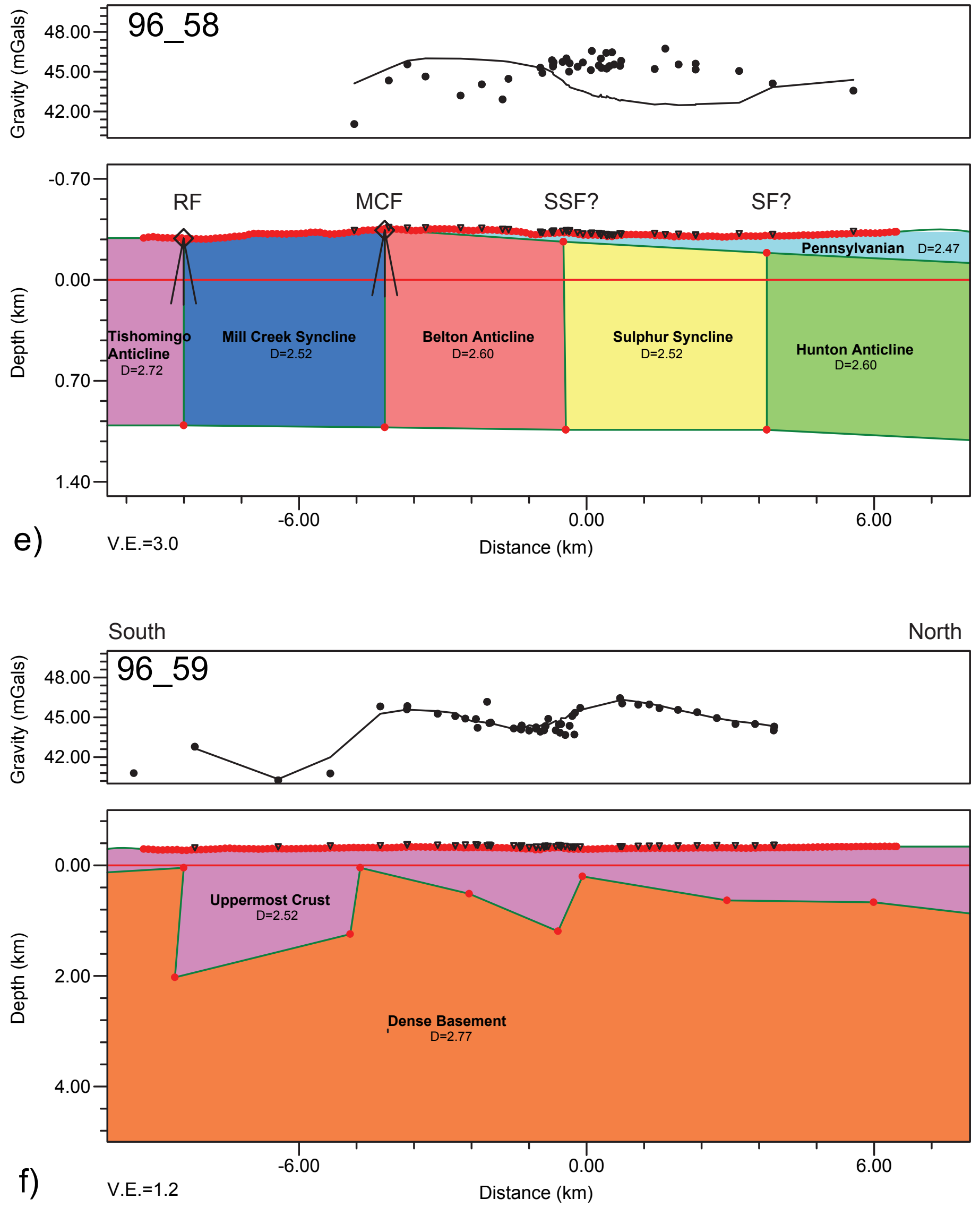

Figure 7 (continued). Two-dimensional gravity models along north-south profiles at: e) $96^{\circ} 58^{\prime} \mathrm{W}$, f) $96^{\circ} 59^{\prime} \mathrm{W}$. 

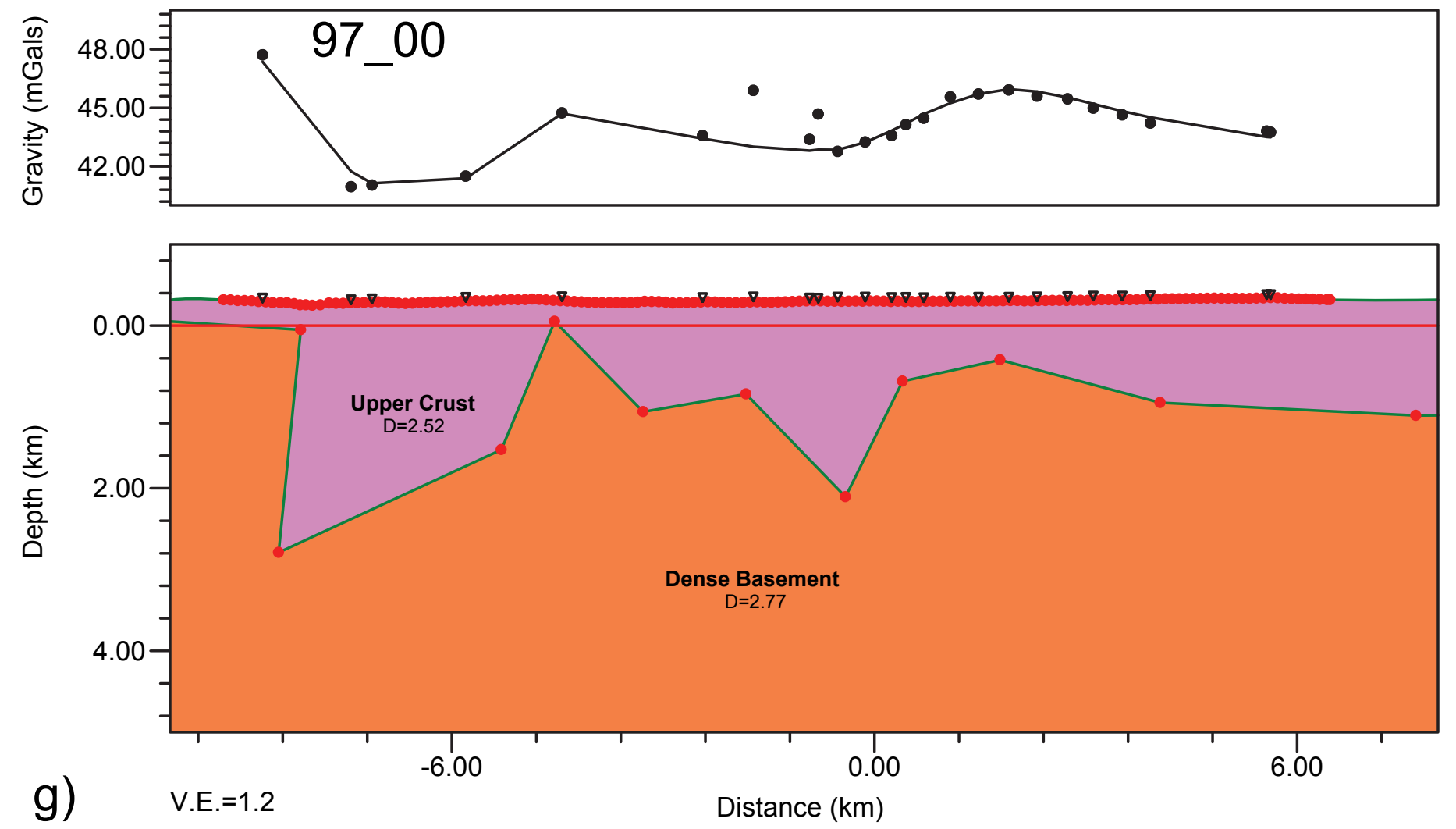

Figure 7 (continued). Two-dimensional gravity models along north-south profiles at: g) $97^{\circ} 00^{\prime} \mathrm{W}$. 

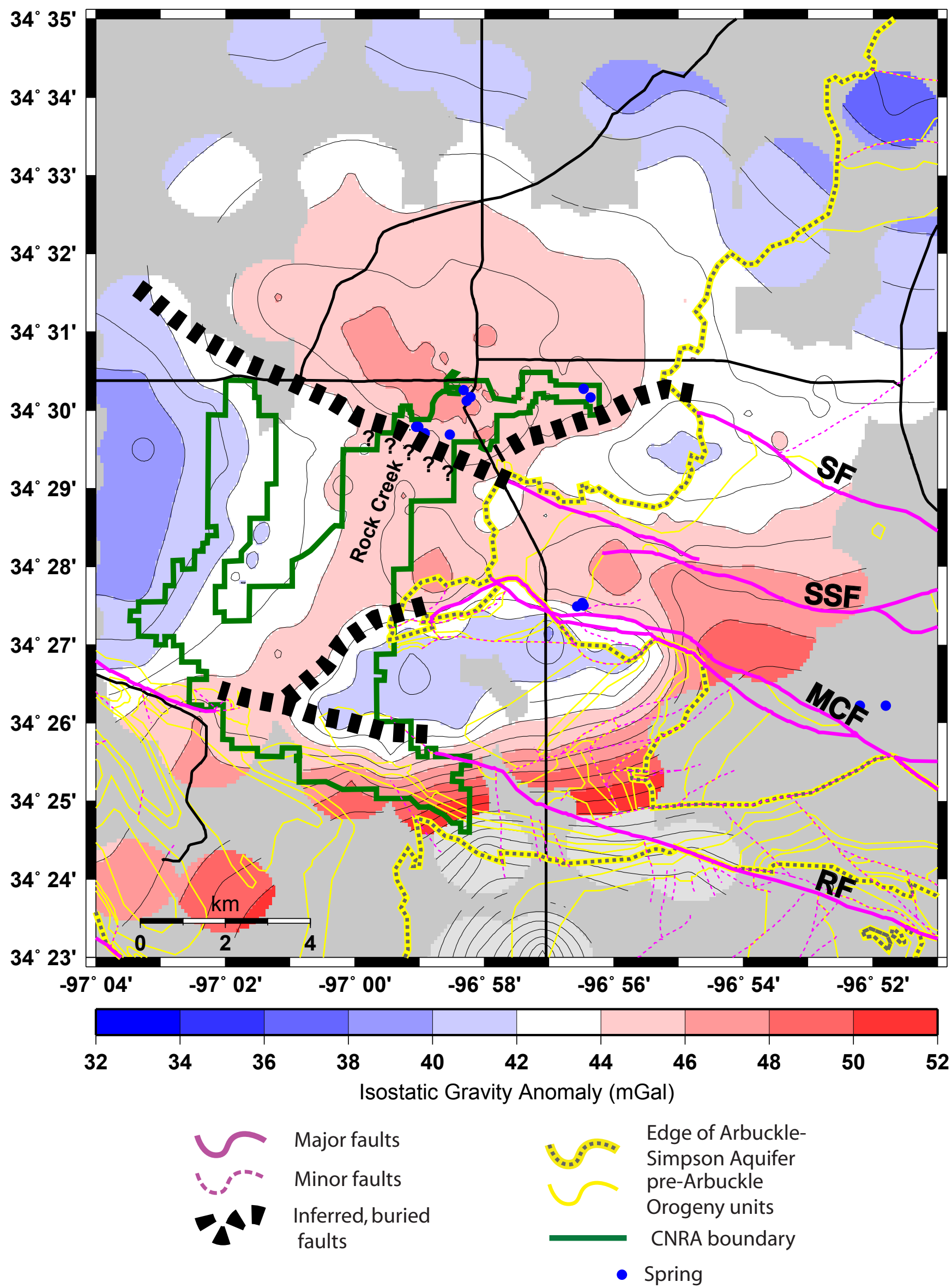

Figure 8. Isostatic gravity anomaly map of the study area, similar to fig. 5 , but with inferred, buried faults indicated by thick dashed lines. Question marks indicate where the inferences are least certain. 


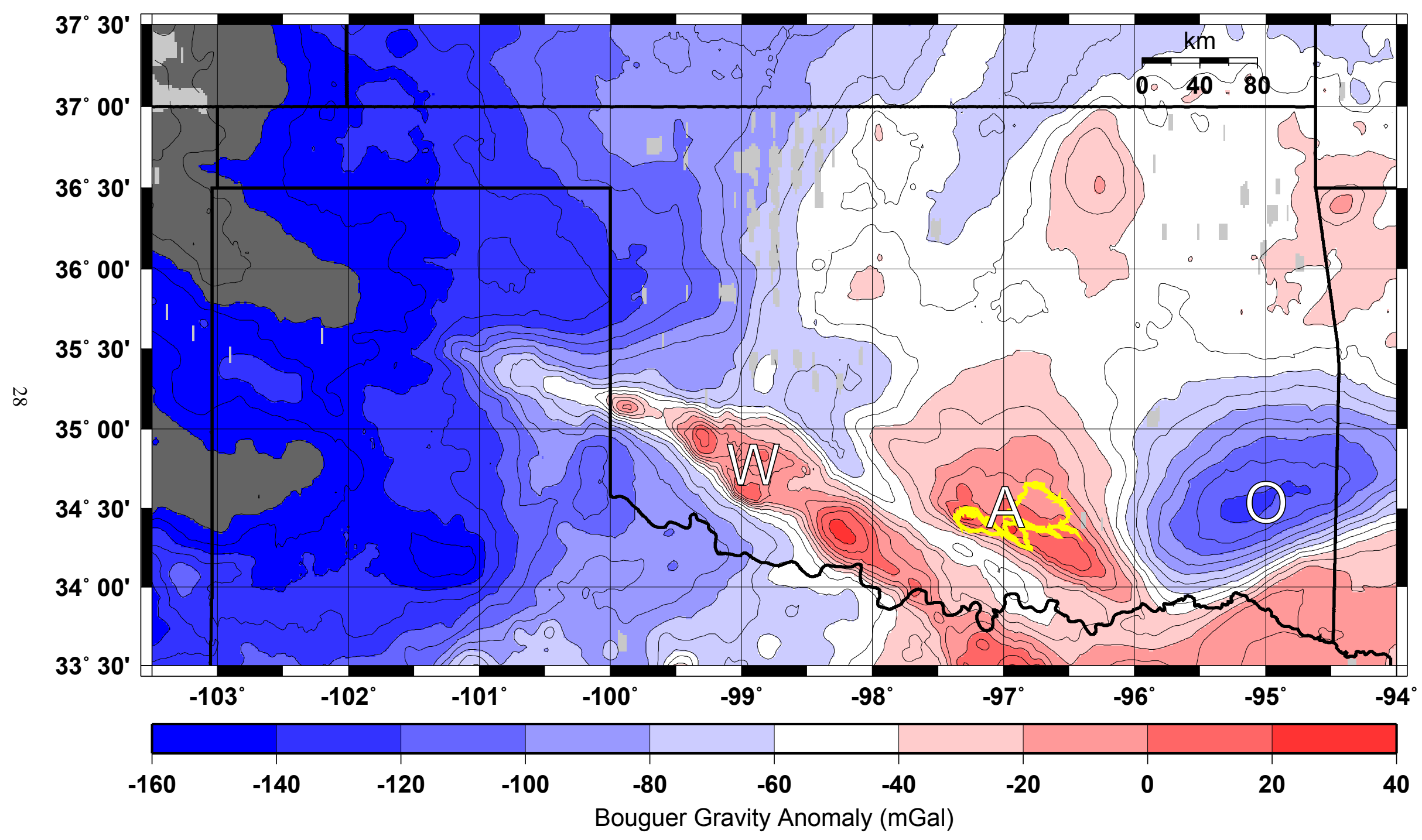

Figure 9. Bouguer gravity anomaly map of the state of Oklahoma and the panhandle of Texas. Contour interval is $10 \mathrm{mGal}$. Yellow line denotes the outcrop area of Arbuckle-Simpson

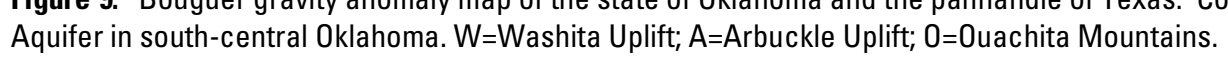



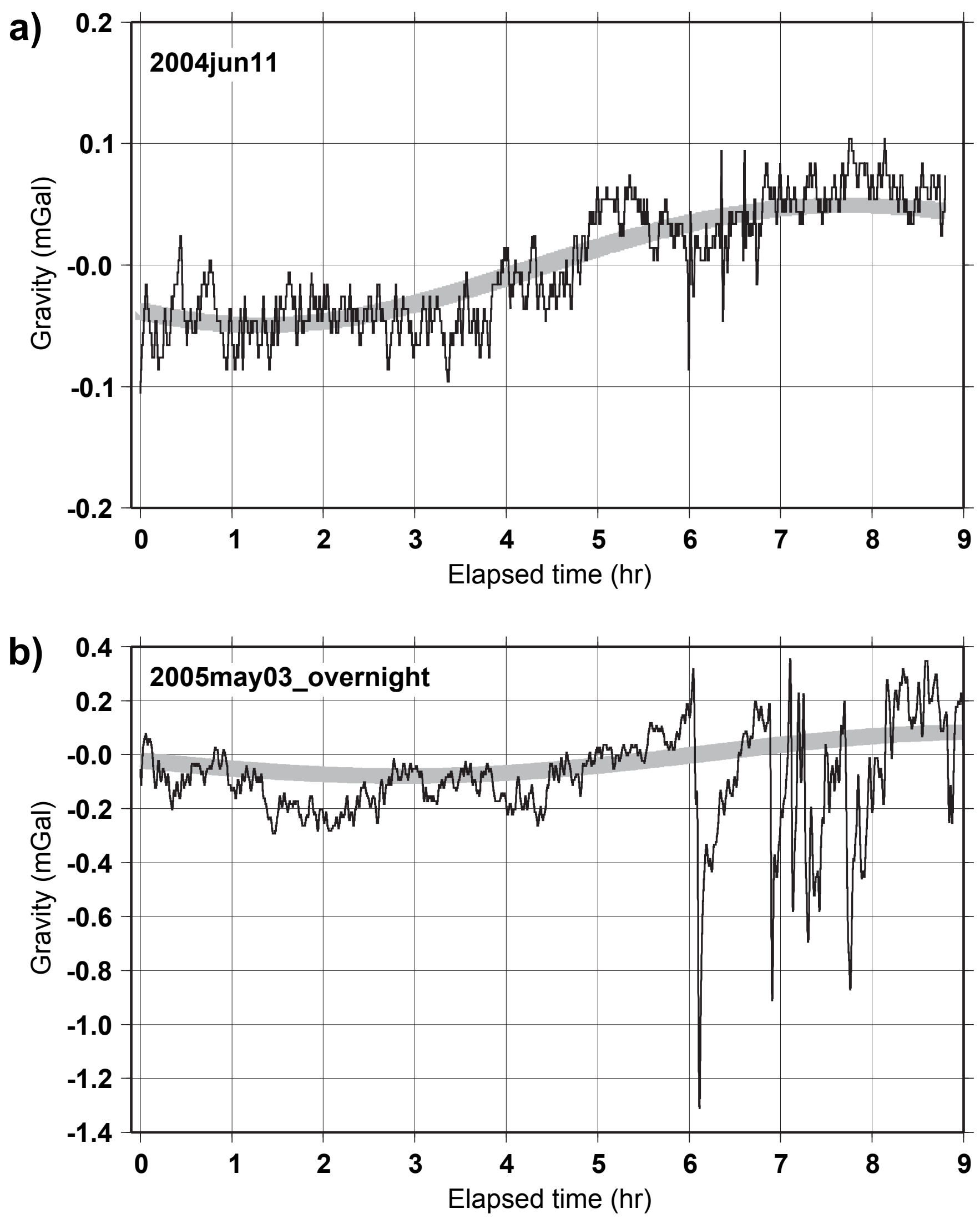

Figure A1. Time-series plot of BGM-5 gravity data (thin line) for 9 hour periods when the vehicle was stationary on A1a) 2004jun11 and $A 1 b)$ 2005may03. Thick gray line indicates predicted tidal accelerations from the positions of the moon and sun. 

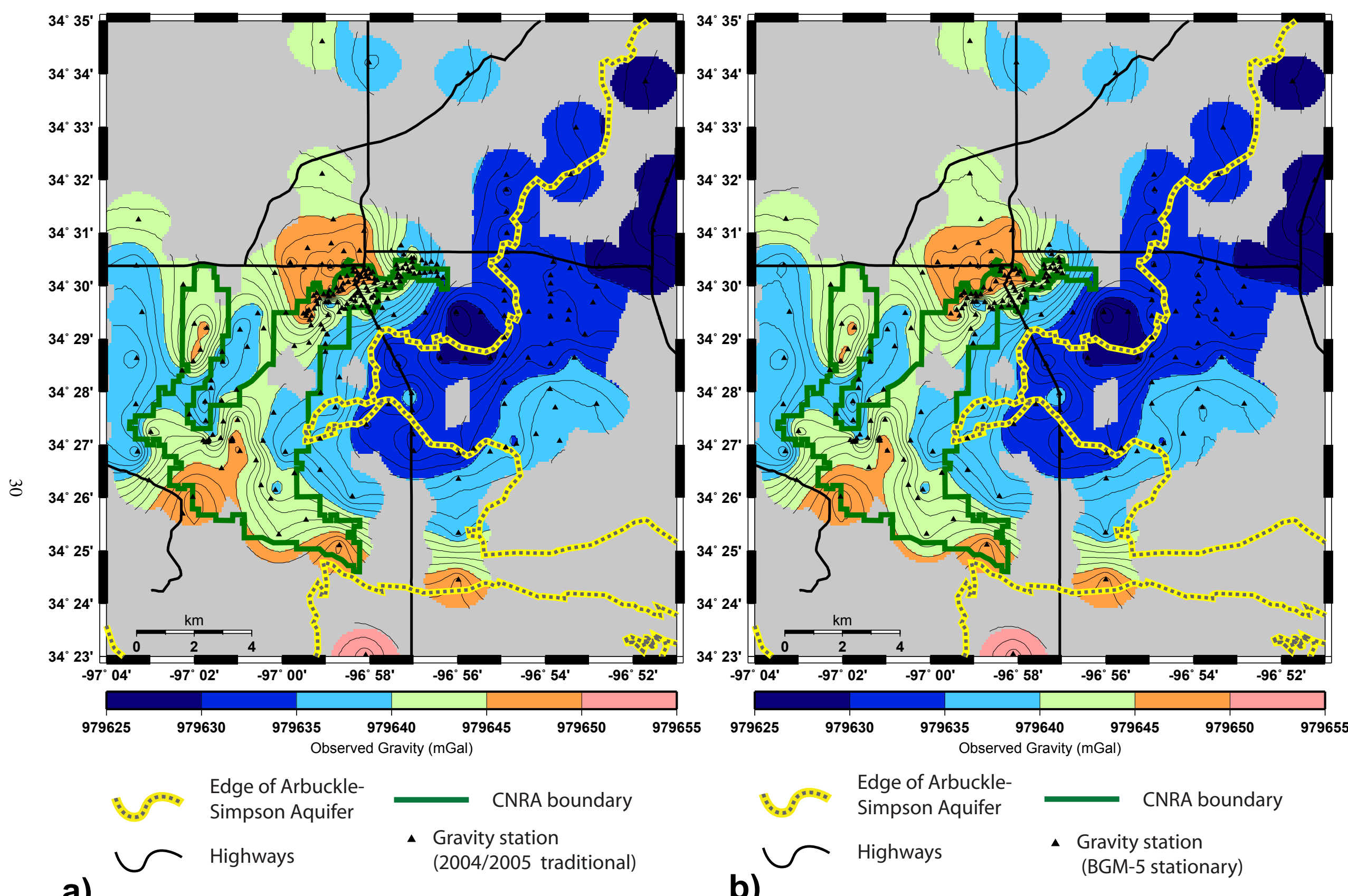

a)

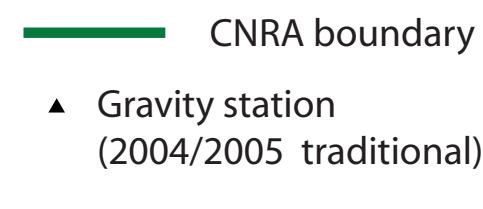

Figure A2. A2a) Map of observed gravity across the study area using the traditional, discrete LaCoste-Romberg gravity stations collected in 2004 and 2005 , contoured every 1 mGal. Because this gravity has not had any elevation effects removed, the dominant gravity signal is anti-correlated with land elevation. A2b) Map of observed gravity across the study area using the continuous BGM-5 values when the vehicle was stationary at LaCoste-Romberg stations, contoured every $1 \mathrm{mGal}$. 


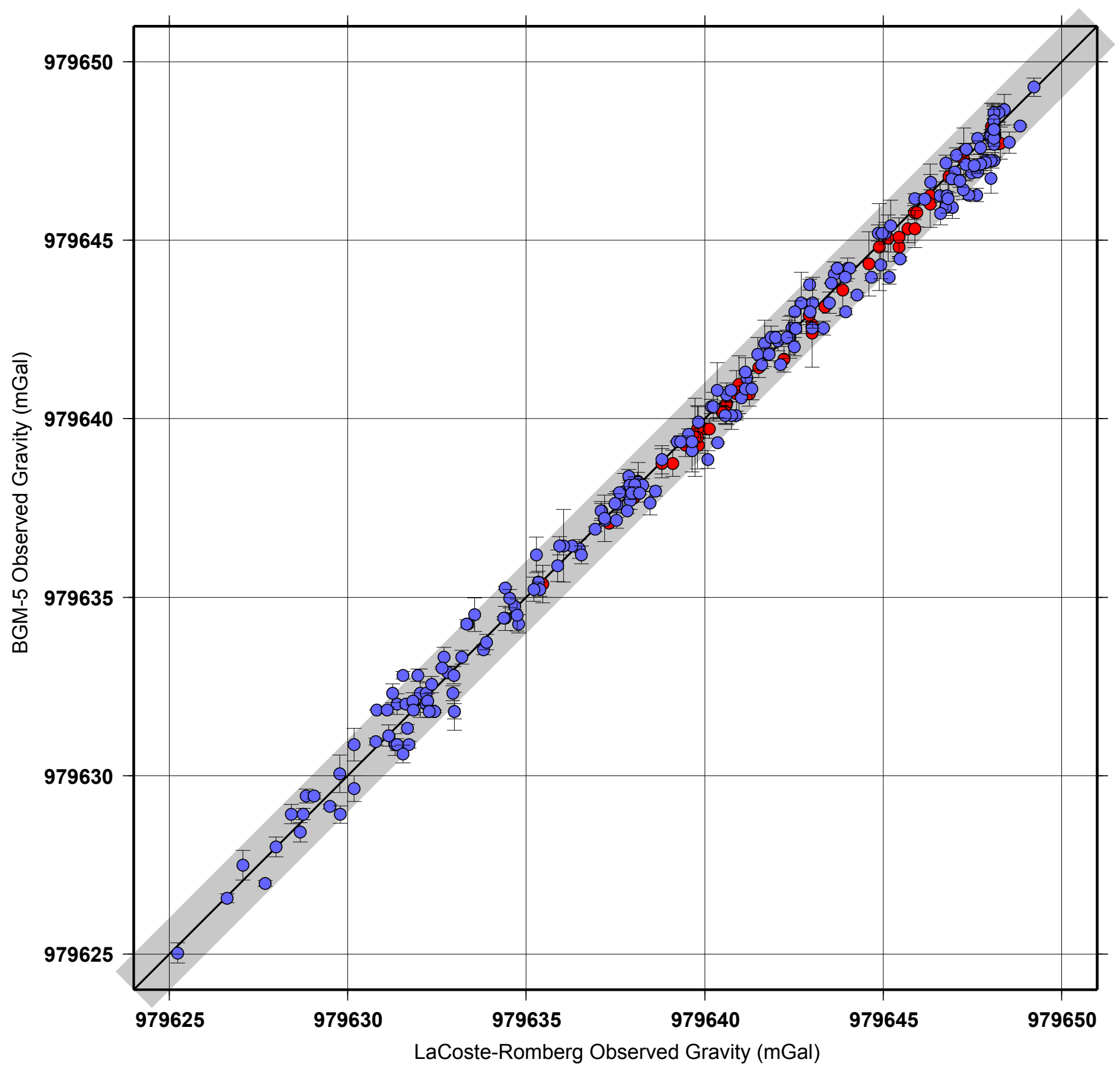

Figure A3. Scatter plot of observed gravity values measured by the LaCoste-Romberg meters versus those of the BGM-5 meters at identical sites. Red symbols are for stations collected in 2004; blue symbols are for stations collected in 2005. Error bars indicate plus and minus one standard-deviation values about the mean gravity measured by the BGM-5 meter when the vehicle was stationary. Gray field about the 1:1 reference line spans $1 \mathrm{mGal}$ vertically and horizontally. 


\section{Appendix: Continuous Gravity Results}

A major component of the geophysical fieldwork conducted in 2004 and 2005 was the use of the BGM-5 gravimeter to collect continuous gravity across the study area. The full analysis of this gravity has yet to be completed, but in this appendix we describe our acquisition strategy and some preliminary results from the continuous gravity observations.

The Bell Aerospace BGM-5 Marine Gravity Meter System is an axially symmetric, forced feedback accelerometer that is mounted on a gyro-stabilized platform. The BGM-5 gravimeter is a successor to the BGM-3 system (Bell and Watts, 1986), and both systems have been deployed on ships and aircraft world-wide. To our knowledge, our experiment is the first deployment of this type of continuous gravity system on a land vehicle. In theory, collecting gravity continuously will allow significantly greater numbers of observations to be made in a field-day relative to traditional stationary gravity collection. Furthermore, by driving a vehicle slowly, observations can be made at close spacing, allowing resolution of shallow density variations. The challenges of collecting gravity in this manner are several-fold: providing sufficient $\mathrm{AC}$ power of adequate quality to the meter electronics, driving the vehicle in ways that allow the platform to remain stable, and acquiring synchronous ancillary data to determine geographic position and to allow correction for motion of the gravity sensor from the raw accelerometer record. The vehicle motions that must be removed are of two types: horizontal velocities via the Eotvos correction (Blakely, 1996) and vertical accelerations of the sensor. These motions are calculated as first and second time-derivatives of GPS locations, described below.

During our two field sessions, the Naval Oceanographic Office (NAVOCEANO) provided a BGM-5 meter under its agreement with the Academic Gravimeter Pool operated by the Woods Hole Oceanographic Institution (WHOI). In 2004, the gravimeter system was mounted in a 21'-long recreational vehicle (RV), and the equipment was powered by a 30 Amp generator. In 2005, the gravimeter system was mounted in a passenger van with its seats removed, and the equipment was powered by a $2.5 \mathrm{~kW}(\sim 22 \mathrm{~A}$ at $110 \mathrm{~V} \mathrm{AC})$ modified-sinewave inverter connected to the van's battery. Overnight, the system was plugged into land power sources. Tests of the power draw of the BGM-5 system indicated that the maximum draw was $\sim 14$ A upon power-up, and the sustained usage was $\sim 11 \mathrm{~A}$ (M. Ducre, personal comm.). Power must be supplied to the BGM-5 sensor at all times or else it requires servicing, and a battery backup provided power to the sensor subsystem when an AC source was disconnected for short times. The AC power provided by the generator and by the inverter, while adequate for powering the gravimeter system electronics, was not of high enough quality to support uninterruptible power supply (UPS) systems - both high-end and low-end UPS units. We never discovered the source of this incompatibility but we suspected problems with the wiring in the RV circuitry and with modified (non-true) sinewave AC from the inverter. Because we did not have a working UPS, transitions from land- to vehicle-power required a complete system shutdown and reboot, a timeconsuming (30-45 min) operation at the beginning and end of each field-day.

The BGM-5 gravimeter system consists of the gyro-stabilized platform that contains the accelerometer sensor, a GPS system that provides time and navigation information, a computer that logs the acceleration and navigation streams and processes the data to provide a smoothed gravity anomaly, and the electronics that supports the other subsystems. For both deployments in 2004 and 2005, we mounted the gyro-stabilized platform on the floor as near as possible to the center-point of the wheels, to minimize motions of the sensor related to the vehicle suspension. The GPS antenna was mounted on the roof of the vehicle, as close to vertically above the sensor as possible. The accelerometer and GPS data streams were recorded at $1 \mathrm{~Hz}$, and frame count output of the sensor was converted to acceleration using bias and scaling calibration factors specific to the individual BGM-5 system. Minor adjustments to the bias were made daily in the study area when we recorded data over local gravity base stations. In addition to the raw, $1 \mathrm{~Hz}$ gravimeter data, the logging computer smoothes the raw readings with a 3-minute halfwidth Gaussian filter, and it calculates and applies Eotvos corrections based on smoothed GPS navigation to generate gravity anomalies. This smoothing filter works well in marine deployments of BGM systems. On ships, the vertical accelerations from heave average to zero over the 6-minute width of the Gaussian filter, so the vertical acceleration correction may be ignored in marine settings. The filtered output is a measure of free-air gravity anomaly. In land vehicle deployments, horizontal velocities are both comparable to and exceed the steaming velocities of marine craft, so land-based Eotvos corrections are of similar and greater magnitude than marine corrections. In land-deployments, the magnitude of vertical accelerations is typically much less than that of ship- 
heave. However, rather than averaging to zero, vertical accelerations are non-zero when traversing land topography, so careful collection of vertical positions is necessary.

The GPS unit integrated with the BGM-5 system is autonomous, and it utilizes the Civilian Access Code signal. To investigate how navigation quality varies among different types of GPS systems, we collected GPS data using two other autonomous, code-based units and using one dual-frequency, carrier-phase-based differential GPS system that consisted of a fixed GPS base station unit and a rover unit. For the differential GPS system (Trimble 4700), the observations were made in real-time-kinematic mode with a radio link in 2004 and in post-processed kinematic mode by recording the GPS waveforms in 2005. All GPS antennas were mounted on the vehicle roof, and their 3-D offsets from the gravimeter sensor were measured. The GPS base stations were established at locations with unobstructed views of the sky and at local highs in elevation. The quality of the GPS navigation varies due to a number of factors: the GPS constellation geometry changes through the day; there are environmental effects at observation sites; and the navigation algorithms within each GPS unit differ. During our field sessions, the GPS constellation geometry was generally very good, with only single $\sim 1$ hour periods of slightly degraded coverage during field-days. In CNRA, tree foliage absorbed some of the GPS signals, and measures of navigational precision degraded noticeably when we were beneath leaf cover. The carrier-phase-based GPS system requires high signal-tonoise reception of the GPS satellite broadcast to retain the high precision of the differential solutions, and we rarely obtained differential-quality navigation within CNRA. (The differential GPS system provides code-based, lowerquality locations when conditions are not sufficient for differential solutions.) In the ranchland surrounding CNRA, trees are much less common and differential GPS solutions were prevalent, although at creek-crossings and near some homes, large trees overhanging the road were often sufficient to cause loss of differential GPS acquisition.

In addition to the multiple GPS observations, we collected vehicle attitude (heading, pitch, and roll) data with an electronic compass. These observations will allow precise calculation of the sensor position by correcting the GPS antenna navigation for the offsets between the gravity sensor and the GPS antenna.

The typical field-day started and ended with a LaCoste-Romberg observation at one or more of the local gravity base-stations, during which time the BGM-5 collected continuous, stationary data. We then drove slowly along the roadways of CNRA, the City of Sulphur, and surrounding areas. We collected data at very slow speeds (5$10 \mathrm{mph}$ ) where it was safe to do so and where high-resolution gravity was deemed most desirable. For the most part, we drove at 10 to $15 \mathrm{mph}$, but occasionally we increased that value to $20 \mathrm{mph}$ and greater. During transits from the NAVOCEANO laboratory at Stennis Space Center, Miss. to the study area and back, we collected data at speeds as great at $70 \mathrm{mph}$. In the study area, we drove with an intent to minimize all accelerations of the vehicle: we accelerated slowly, avoided sharp stops, tried to maintain constant survey speeds, made turns as smoothly as possible, and avoided rough patches of roadway. We continuously monitored all data streams, and we designed surveys to cover all of the park roads in CNRA and the publicly accessible roads in the surrounding area. In a few instances that were facilitated by CNRA Resources personnel, we obtained permission to collect observations on private ranches.

The partial analysis of the BGM-5 data presented in this report consists only of times when the vehicle was stationary. This subset of the data is by far the easiest to analyze because corrections due to sensor motion are, by definition, zero. Most of the times that the vehicle was stationary were times either when the vehicle was parked overnight or when the vehicle was stopped for 3 to 10 minutes while acquiring a traditional LaCoste-Romberg station. Thus, these continuous gravity observations do not contribute new information to the gravity field as described in the main part of this report. That said, this analysis of stationary BGM-5 data is critical in establishing the signal and noise characteristics of the BGM-5 system to help guide filter design and navigation corrections for the moving BGM-5 data.

Figure A1 displays the BGM-5 gravity output of the NAVOCEANO smoothing filter (3-minute half-width Gaussian) for two 9-hour periods when the vehicle was parked. On 2004jun11 (fig. A1a), the measured gravity fluctuations varied by $<0.2 \mathrm{mGal}$, and much of the variation can be explained by the $0.1 \mathrm{mGal}$ signal predicted for lunar and solar tidal accelerations and the Earth's response to them. The residual of filtered gravity vs. predicted tidal accelerations has a maximum of $0.1 \mathrm{mGal}$, with agreement generally better than $0.05 \mathrm{mGal}$. This agreement between stationary BGM gravity and tidal predictions is typical of that in quiet, laboratory-bench deployments (R. Herr, personal commun.). The filtered gravity is not randomly distributed about the predicted gravity line; there are oscillations with periods of tens of minutes to two hours. The example from 2004jun11 is typical of the best stationary field-deployment periods that we measured. In other cases, such the overnight period starting on 2005 may03 (fig. A1b), the filtered gravity has periods of relative quiet and others of higher noise. Prior to 6 hours 
of elapsed time, the BGM-5 gravity varies slowly and broadly in-synch with the predicted tidal acceleration, although it is somewhat noisier than the 2004jun 11 case. After 6 hours of elapsed time, there are abrupt changes in filtered gravity, with steps of $0.5-2 \mathrm{mGal}$, and the measured gravity does not reflect the lower-amplitude predicted tidal accelerations. The cause of these rapid excursions is known in some cases but not in others. For instance, in some of the overnight deployments, the temperature inside of the vehicle decreased below the minimum operating temperature, $15^{\circ} \mathrm{C}\left(59^{\circ} \mathrm{F}\right)$, of the BGM-5 system and the measurements became erratic. When temperature changes were not a factor, we inspected the electronic compass records to see if there were vehicle motions that might indicate physical disturbance. In all of these cases, we did not detect such a physical disturbance, so the source of the noise in the gravimeter is unknown. Based on noise observed on some of the early overnight tests in 2005, we conducted a number of tilt and damp tests of the BGM-5 gyro-stabilized platform system when the vehicle was parked in an effort to improve the platform's stability and calibration. After these tests, noise levels were decreased, as expected, but in some cases they were still greater than the quiet results observed in times such as 2004jun11 (fig. A1a).

During extended, stationary time periods when the meter is quiet (for example, fig. A1a), filtered BGM-5 gravity data are as precise as $0.05 \mathrm{mGal}$. This precision is not as good as that obtainable by LaCoste-Romberg Gmeter measurements (estimated to be $0.02 \mathrm{mGal}$ through a typical survey day), but it is better than the gravity uncertainty related to elevation precision, where a $1 \mathrm{~m}$ uncertainty in elevation (common to many mid-level GPS systems) corresponds to a $\sim 0.2 \mathrm{mGal}$ uncertainty in elevation effect (free-air plus Bouguer terms). During noisy times such as the latter part of fig. A1b, the filtered BGM- 5 data can be considered to be good only to 1 to 2 mGal, seriously limiting its utility for land-surveys at those times. In the 2004 and 2005 survey days, the vehicle temperature was always within the BGM-5 operating range, so that source of error observed in some overnight deployments is not present during the surveys. The collection of $>250$ traditional LaCoste-Romberg gravity stations in this study allows comparisons with the BGM-5 gravity values, permitting the identification of times of BGM-5 noise and their subsequent omission from further analysis.

As a first step in this analysis, we compare observed gravity values measured by traditional meters with those measured by the BGM- 5 when the vehicle was stationary. To obtain a BGM- 5 gravity value when stopped, we extracted times when the unfiltered GPS velocity was below an empirically-derived threshold of $0.02 \mathrm{~m} / \mathrm{sec}$ ( 0.05 miles/hour). We then considered only those time intervals longer than 2 minutes. Because the system does not respond instantaneously to changes in acceleration, we investigated how long it took after stopping for the raw accelerometer signal to reach a near-constant value. Most of the decay of the raw signal from its transient to its near-constant state occurs within the first 30 seconds after the speed threshold is met. This indicates that the timeconstant of the BGM-5 system is considerably less than the 3-minute half-width Gaussian filter utilized in marine applications, and it suggests that less smoothing will be necessary in the moving, land-vehicle application. To be conservative, we omitted the first 60 seconds of stationary gravimeter data to avoid the transient, and then we passed the remaining data through a 3-point median filter to exclude any single-point spikes before averaging the data to provide a single gravity value. The standard deviations of the raw gravity values contributing to each stationary gravity observation ranged between $0.02 \mathrm{mGal}$ and about $0.3 \mathrm{mGal}$. Finally, bias corrections were made for the BGM-5 stationary gravity values to force them to match the observed gravity values at the gravity base stations at the beginning and end of each field day. These bias corrections varied by 1 to $2 \mathrm{mGal}$ from day to day and may be related to the operational requirement of cycling the power to the BGM-5 system twice per day.

The observed gravity values measured by the LaCoste-Romberg meter (fig. A2a) with those of the BGM-5 when it was stationary (fig. A2b) are strikingly similar. The major features of the observed gravity field are consistently recorded at the $1 \mathrm{mGal}$ contour level using both data sets. Because these gravity values have not had any elevation effects incorporated, the dominant gravity signal of these maps is anti-correlated with land elevation. Individual BGM-5 "station" gravity values match their LaCoste-Romberg counterparts by less than the $1 \mathrm{mGal}$ contour interval in all instances.

Another display of the agreement of LaCoste-Romberg and stationary BGM-5 gravity observations is shown in fig. A3, where uncertainties of the BGM-5 values are plotted as standard-deviation error bars of the raw gravity counts. The gray band about the 1:1 line has a vertical dimension of $1 \mathrm{mGal}$. The agreement in observed gravity between the traditional and continuous meters points to the promise of this continuous technique in other land studies. 
Table A1. Principal facts for gravity stations collected in 2004 and 2005 in south-central Oklahoma

[Datums: latitude and longitude, NAD27; elevations, NGVD29. FAA, free-air gravity anomaly; ITC, inner terrain correction calculated out to 2 $\mathrm{km}$; TTC, total terrain correction; CBA, complete Bouguer gravity anomaly, ISO, isostatic gravity anomaly]

\begin{tabular}{|c|c|c|c|c|c|c|c|c|c|}
\hline Station & $\begin{array}{c}\text { Latitude } \\
\text { north } \\
\text { (deg min) }\end{array}$ & $\begin{array}{c}\text { Longitude } \\
\text { west } \\
\text { (deg min) }\end{array}$ & $\begin{array}{c}\text { Elevation } \\
\text { (m) }\end{array}$ & $\begin{array}{c}\text { Observed } \\
\text { gravity } \\
\text { (mGal) }\end{array}$ & $\begin{array}{c}\text { FAA } \\
\text { (mGal) }\end{array}$ & $\begin{array}{c}\text { ITC } \\
\text { (mGal) }\end{array}$ & $\begin{array}{c}\text { TTC } \\
\text { (mGal) }\end{array}$ & $\begin{array}{c}\text { CBA } \\
\text { (mGal) }\end{array}$ & $\begin{array}{c}\text { ISO } \\
\text { (mGal) }\end{array}$ \\
\hline GEM001 & 3430.03 & -9658.34 & 308.2 & 979643.64 & 48.16 & 0.06 & 0.13 & 13.38 & 46.07 \\
\hline GEM002 & 3430.26 & -9658.29 & 286.0 & 979648.38 & 45.70 & 0.05 & 0.11 & 13.43 & 46.15 \\
\hline GEM003 & 3430.22 & -9656.98 & 316.9 & 979641.12 & 48.04 & 0.10 & 0.19 & 12.34 & 44.96 \\
\hline GEM004 & 3429.81 & -9657.91 & 321.4 & 979640.61 & 49.50 & 0.05 & 0.14 & 13.24 & 45.87 \\
\hline GEM005 & 3430.34 & -9658.35 & 289.7 & 979648.08 & 46.43 & 0.04 & 0.10 & 13.73 & 46.47 \\
\hline GEM006 & 3426.55 & -9701.38 & 269.3 & 979644.89 & 42.27 & 0.02 & 0.04 & 11.82 & 44.24 \\
\hline GEM007 & 3426.88 & -9700.96 & 266.3 & 979646.32 & 42.34 & 0.03 & 0.05 & 12.23 & 44.67 \\
\hline GEM008 & 3427.07 & -9701.12 & 268.4 & 979645.88 & 42.26 & 0.04 & 0.06 & 11.93 & 44.41 \\
\hline GEM009 & 3427.11 & -9701.13 & 267.4 & 979645.95 & 41.98 & 0.04 & 0.06 & 11.76 & 44.25 \\
\hline GEM010 & 3427.06 & -9701.15 & 270.6 & 979645.44 & 42.53 & 0.04 & 0.06 & 11.94 & 44.42 \\
\hline GEM011 & 3427.10 & -9701.15 & 270.1 & 979645.70 & 42.56 & 0.04 & 0.06 & 12.03 & 44.51 \\
\hline GEM012 & 3427.09 & -9701.14 & 269.2 & 979645.89 & 42.50 & 0.04 & 0.06 & 12.07 & 44.55 \\
\hline GEM013 & 3427.46 & -9701.01 & 268.7 & 979645.14 & 41.08 & 0.04 & 0.06 & 10.71 & 43.24 \\
\hline GEM014 & 3427.44 & -9701.34 & 289.6 & 979640.90 & 43.32 & 0.09 & 0.12 & 10.64 & 43.18 \\
\hline GEM015 & 3427.12 & -9701.40 & 295.0 & 979640.03 & 44.56 & 0.12 & 0.16 & 11.32 & 43.82 \\
\hline GEM016 & 3427.18 & -9701.58 & 293.7 & 979639.83 & 43.86 & 0.07 & 0.11 & 10.72 & 43.24 \\
\hline GEM017 & 3427.10 & -9701.66 & 291.1 & 979640.13 & 43.49 & 0.10 & 0.14 & 10.66 & 43.17 \\
\hline GEM018 & 3427.08 & -9701.68 & 290.8 & 979640.59 & 43.89 & 0.13 & 0.16 & 11.12 & 43.63 \\
\hline GEM019 & 3427.06 & -9701.68 & 285.0 & 979641.26 & 42.80 & 0.07 & 0.10 & 10.62 & 43.13 \\
\hline GEM020 & 3427.04 & -9701.70 & 282.1 & 979642.22 & 42.89 & 0.07 & 0.10 & 11.03 & 43.54 \\
\hline GEM021 & 3427.04 & -9701.72 & 277.3 & 979643.01 & 42.18 & 0.06 & 0.08 & 10.86 & 43.37 \\
\hline GEM022 & 3427.04 & -9701.75 & 272.9 & 979643.87 & 41.68 & 0.06 & 0.08 & 10.85 & 43.37 \\
\hline GEM023 & 3427.08 & -9701.80 & 276.2 & 979643.36 & 42.14 & 0.06 & 0.08 & 10.94 & 43.47 \\
\hline GEM024 & 3427.81 & -9701.75 & 313.0 & 979635.47 & 44.59 & 0.14 & 0.22 & 9.36 & 41.98 \\
\hline GEM025 & 3427.57 & -9702.11 & 295.6 & 979639.46 & 43.55 & 0.15 & 0.19 & 10.26 & 42.87 \\
\hline GEM026 & 3427.83 & -9701.38 & 293.2 & 979640.49 & 43.45 & 0.06 & 0.10 & 10.35 & 42.95 \\
\hline GEM027 & 3428.21 & -9701.61 & 303.3 & 979638.01 & 43.57 & 0.10 & 0.15 & 9.38 & 42.05 \\
\hline GEM028 & 3428.03 & -9701.04 & 296.4 & 979639.80 & 43.49 & 0.08 & 0.12 & 10.05 & 42.65 \\
\hline GEM029 & 3428.84 & -9700.79 & 307.2 & 979639.10 & 44.98 & 0.04 & 0.10 & 10.29 & 42.98 \\
\hline GEM030 & 3429.48 & -9700.55 & 315.7 & 979638.81 & 46.40 & 0.08 & 0.15 & 10.81 & 43.57 \\
\hline GEM031 & 3428.79 & -9701.86 & 271.9 & 979645.45 & 40.49 & 0.05 & 0.07 & 9.77 & 42.54 \\
\hline GEM032 & 3429.20 & -9701.71 & 268.3 & 979646.32 & 39.68 & 0.06 & 0.08 & 9.37 & 42.18 \\
\hline GEM033 & 3428.75 & -9701.36 & 307.6 & 979638.12 & 44.24 & 0.07 & 0.13 & 9.54 & 42.26 \\
\hline GEM034 & 3429.49 & -9659.91 & 294.9 & 979643.31 & 44.48 & 0.02 & 0.06 & 11.15 & 43.87 \\
\hline GEM035 & 3429.92 & -9658.61 & 292.8 & 979646.85 & 46.77 & 0.05 & 0.11 & 13.71 & 46.41 \\
\hline GEM036 & 3429.91 & -9658.25 & 309.1 & 979643.10 & 48.06 & 0.04 & 0.11 & 13.17 & 45.84 \\
\hline GEM037 & 3425.70 & -9702.26 & 246.0 & 979650.04 & 41.44 & 0.04 & 0.06 & 13.64 & 46.00 \\
\hline GEM038 & 3425.30 & -9700.07 & 289.9 & 979643.01 & 48.53 & 0.11 & 0.15 & 15.85 & 47.96 \\
\hline GEM039 & 3425.10 & -9658.69 & 268.5 & 979648.29 & 47.47 & 0.05 & 0.08 & 17.15 & 49.12 \\
\hline GEM040 & 3423.03 & -9658.09 & 294.7 & 979652.74 & 62.91 & 0.01 & 0.06 & 29.61 & 61.16 \\
\hline GEM041 & 3417.33 & -9658.46 & 237.3 & 979621.12 & 21.58 & 0.02 & 0.01 & -5.29 & 25.24 \\
\hline GEM042 & 3426.70 & -9700.59 & 274.1 & 979644.60 & 43.27 & 0.05 & 0.07 & 12.3 & 44.68 \\
\hline GEM043 & 3427.07 & -9700.43 & 299.4 & 979639.80 & 45.77 & 0.28 & 0.33 & 12.19 & 44.60 \\
\hline GEM044 & 3427.60 & -9700.19 & 306.0 & 979639.72 & 46.96 & 0.12 & 0.18 & 12.49 & 44.96 \\
\hline GEM045 & 3426.86 & -9659.92 & 297.3 & 979637.32 & 42.93 & 0.07 & 0.12 & 9.38 & 41.72 \\
\hline GEM046 & 3426.46 & -9659.72 & 276.1 & 979640.96 & 40.60 & 0.04 & 0.07 & 9.40 & 41.67 \\
\hline GEM047 & 3425.98 & -9700.26 & 267.8 & 979641.52 & 39.24 & 0.02 & 0.04 & 8.96 & 41.20 \\
\hline GEM048 & 3425.58 & -9659.45 & 267.3 & 979642.93 & 41.08 & 0.07 & 0.10 & 10.91 & 43.02 \\
\hline GEM102 & 3429.84 & -9658.95 & 283.1 & 979647.88 & 44.91 & 0.09 & 0.14 & 12.99 & 45.70 \\
\hline GEM103 & 3429.84 & -9659.05 & 282.4 & 979647.62 & 44.42 & 0.13 & 0.18 & 12.63 & 45.35 \\
\hline
\end{tabular}




\begin{tabular}{|c|c|c|c|c|c|c|c|c|c|}
\hline GEM104 & 3429.80 & -9658.93 & 284.6 & 979647.40 & 44.94 & 0.13 & 0.18 & 12.89 & 45.59 \\
\hline GEM105 & 3429.83 & -9658.83 & 282.3 & 979648.06 & 44.87 & 0.11 & 0.16 & 13.06 & 45.76 \\
\hline GEM106 & 3430.27 & -9658.38 & 286.0 & 979648.54 & 45.85 & 0.05 & 0.11 & 13.57 & 46.30 \\
\hline GEM107 & 3430.18 & -9658.52 & 286.7 & 979648.67 & 46.33 & 0.05 & 0.11 & 13.97 & 46.69 \\
\hline GEM108 & 3430.15 & -9658.67 & 284.6 & 979648.87 & 45.92 & 0.08 & 0.13 & 13.82 & 46.55 \\
\hline GEM109 & 3429.96 & -9658.76 & 282.0 & 979648.83 & 45.35 & 0.09 & 0.14 & 13.56 & 46.28 \\
\hline GEM110 & 3429.91 & -9658.92 & 285.6 & 979647.97 & 45.68 & 0.05 & 0.10 & 13.44 & 46.16 \\
\hline GEM111 & 3429.71 & -9659.22 & 284.3 & 979646.51 & 44.08 & 0.08 & 0.13 & 12.02 & 44.73 \\
\hline GEM112 & 3429.57 & -9659.26 & 294.8 & 979644.67 & 45.69 & 0.07 & 0.12 & 12.43 & 45.12 \\
\hline GEM113 & 3429.65 & -9659.19 & 288.4 & 979645.16 & 44.08 & 0.09 & 0.14 & 11.57 & 44.27 \\
\hline GEM114 & 3429.81 & -9659.28 & 279.3 & 979647.49 & 43.41 & 0.06 & 0.11 & 11.88 & 44.60 \\
\hline GEM115 & 3429.76 & -9659.14 & 293.4 & 979643.95 & 44.26 & 0.11 & 0.16 & 11.20 & 43.91 \\
\hline GEM116 & 3429.47 & -9659.51 & 277.5 & 979646.94 & 42.76 & 0.05 & 0.09 & 11.43 & 44.13 \\
\hline GEM117 & 3429.43 & -9659.32 & 279.3 & 979646.75 & 43.18 & 0.11 & 0.16 & 11.71 & 44.39 \\
\hline GEM118 & 3429.54 & -9659.38 & 287.7 & 979645.47 & 44.35 & 0.07 & 0.11 & 11.88 & 44.58 \\
\hline GEM119 & 3429.45 & -9658.95 & 296.5 & 979643.33 & 45.05 & 0.07 & 0.12 & 11.59 & 44.24 \\
\hline GEM120 & 3429.50 & -9658.70 & 298.5 & 979643.65 & 45.91 & 0.10 & 0.16 & 12.26 & 44.90 \\
\hline GEM121 & 3429.69 & -9659.01 & 312.2 & 979640.88 & 47.11 & 0.19 & 0.26 & 12.01 & 44.70 \\
\hline GEM122 & 3429.69 & -9658.93 & 322.8 & 979638.47 & 47.95 & 0.42 & 0.51 & 11.91 & 44.59 \\
\hline GEM123 & 3429.68 & -9658.74 & 319.7 & 979639.65 & 48.2 & 0.29 & 0.37 & 12.37 & 45.04 \\
\hline GEM124 & 3429.56 & -9658.56 & 313.9 & 979640.75 & 47.68 & 0.13 & 0.20 & 12.34 & 44.98 \\
\hline GEM125 & 3429.58 & -9658.63 & 308.2 & 979642.12 & 47.27 & 0.09 & 0.16 & 12.52 & 45.17 \\
\hline GEM126 & 3429.66 & -9658.52 & 297.6 & 979644.27 & 46.02 & 0.09 & 0.15 & 12.47 & 45.13 \\
\hline GEM127 & 3429.71 & -9658.33 & 310.1 & 979643.01 & 48.57 & 0.06 & 0.13 & 13.58 & 46.23 \\
\hline GEM128 & 3429.59 & -9658.36 & 316.7 & 979640.57 & 48.33 & 0.09 & 0.17 & 12.63 & 45.26 \\
\hline GEM129 & 3429.62 & -9658.19 & 317.3 & 979641.03 & 48.92 & 0.06 & 0.14 & 13.13 & 45.75 \\
\hline GEM130 & 3429.61 & -9658.04 & 311.7 & 979642.45 & 48.65 & 0.06 & 0.13 & 13.48 & 46.09 \\
\hline GEM131 & 3430.11 & -9658.34 & 303.2 & 979644.98 & 47.82 & 0.11 & 0.17 & 13.66 & 46.36 \\
\hline GEM132 & 3430.22 & -9657.99 & 295.1 & 979647.06 & 47.26 & 0.06 & 0.12 & 13.97 & 46.67 \\
\hline GEM133 & 3430.29 & -9658.11 & 292.8 & 979647.65 & 47.03 & 0.05 & 0.11 & 13.99 & 46.70 \\
\hline GEM134 & 3430.31 & -9658.03 & 291.3 & 979647.01 & 45.9 & 0.09 & 0.15 & 13.07 & 45.78 \\
\hline GEM135 & 3430.26 & -9657.93 & 291.7 & 979646.76 & 45.84 & 0.09 & 0.16 & 12.97 & 45.67 \\
\hline GEM136 & 3430.13 & -9657.89 & 300.4 & 979646.26 & 48.22 & 0.06 & 0.13 & 14.33 & 47.01 \\
\hline GEM137 & 3429.48 & -9659.44 & 278.0 & 979646.88 & 42.86 & 0.06 & 0.10 & 11.47 & 44.16 \\
\hline GEM138 & 3429.52 & -9659.43 & 279.8 & 979646.70 & 43.16 & 0.05 & 0.09 & 11.57 & 44.27 \\
\hline GEM139 & 3430.26 & -9656.48 & 328.3 & 979639.69 & 50.08 & 0.08 & 0.18 & 13.09 & 45.67 \\
\hline GEM140 & 3430.15 & -9656.33 & 330.6 & 979638.92 & 50.18 & 0.09 & 0.19 & 12.94 & 45.50 \\
\hline GEM141 & 3430.18 & -9656.45 & 328.2 & 979639.62 & 50.08 & 0.09 & 0.19 & 13.11 & 45.68 \\
\hline GEM142 & 3430.26 & -9656.61 & 324.0 & 979640.47 & 49.52 & 0.07 & 0.17 & 13.00 & 45.59 \\
\hline GEM143 & 3430.24 & -9656.74 & 321.1 & 979640.90 & 49.11 & 0.07 & 0.16 & 12.90 & 45.50 \\
\hline GEM144 & 3430.24 & -9656.86 & 319.1 & 979641.31 & 48.89 & 0.07 & 0.16 & 12.91 & 45.52 \\
\hline GEM145 & 3429.50 & -9657.97 & 308.1 & 979642.06 & 47.27 & 0.08 & 0.15 & 12.54 & 45.13 \\
\hline GEM146 & 3427.19 & -9657.01 & 319.5 & 979631.38 & 43.37 & 0.02 & 0.11 & 7.30 & 39.47 \\
\hline GEM147 & 3426.88 & -9657.00 & 320.3 & 979631.63 & 44.31 & 0.04 & 0.13 & 8.17 & 40.29 \\
\hline GEM148 & 3426.83 & -9655.97 & 321.7 & 979632.18 & 45.34 & 0.04 & 0.13 & 9.05 & 41.08 \\
\hline GEM149 & 3427.07 & -9653.67 & 328.3 & 979638.93 & 53.81 & 0.02 & 0.12 & 16.76 & 48.62 \\
\hline GEM150 & 3427.20 & -9654.21 & 334.5 & 979637.54 & 54.16 & 0.02 & 0.13 & 16.41 & 48.34 \\
\hline GEM151 & 3427.02 & -9654.66 & 348.0 & 979634.41 & 55.44 & 0.03 & 0.17 & 16.20 & 48.14 \\
\hline GEM152 & 3426.95 & -9654.90 & 336.4 & 979635.88 & 53.43 & 0.03 & 0.14 & 15.48 & 47.43 \\
\hline GEM153 & 3426.87 & -9655.26 & 319.4 & 979635.34 & 47.75 & 0.07 & 0.16 & 11.74 & 43.72 \\
\hline GEM154 & 3426.92 & -9655.63 & 313.7 & 979634.36 & 44.95 & 0.06 & 0.14 & 9.56 & 41.58 \\
\hline GEM155 & 3424.45 & -9655.98 & 296.4 & 979647.32 & 56.03 & 0.03 & 0.09 & 22.56 & 54.18 \\
\hline GEM156 & 3426.35 & -9655.98 & 306.2 & 979636.49 & 45.56 & 0.02 & 0.09 & 10.98 & 42.93 \\
\hline GEM157 & 3428.63 & -9655.83 & 354.4 & 979630.80 & 51.52 & 0.04 & 0.19 & 11.59 & 43.88 \\
\hline GEM158 & 3429.02 & -9654.93 & 355.8 & 979629.77 & 50.38 & 0.03 & 0.18 & 10.27 & 42.55 \\
\hline GEM159 & 3434.21 & -9658.02 & 338.7 & 979637.74 & 45.77 & 0.05 & 0.16 & 7.58 & 40.73 \\
\hline GEM160 & 3436.29 & -9659.09 & 333.7 & 979638.13 & 41.69 & 0.06 & 0.15 & 4.05 & 37.47 \\
\hline GEM161 & 3434.61 & -9659.08 & 325.2 & 979640.62 & 43.93 & 0.05 & 0.13 & 7.23 & 40.49 \\
\hline
\end{tabular}




\begin{tabular}{|c|c|c|c|c|c|c|c|c|c|}
\hline GEM162 & 3432.11 & -9659.08 & 312.5 & 979643.63 & 46.53 & 0.03 & 0.09 & 11.24 & 44.23 \\
\hline GEM163 & 3430.40 & -9659.08 & 288.7 & 979648.13 & 46.10 & 0.03 & 0.08 & 13.49 & 46.28 \\
\hline GEM164 & 3430.38 & -9703.32 & 305.5 & 979637.91 & 41.09 & 0.03 & 0.08 & 6.58 & 39.63 \\
\hline GEM165 & 3431.25 & -9703.27 & 303.2 & 979641.68 & 42.92 & 0.03 & 0.08 & 8.67 & 41.81 \\
\hline GEM166 & 3430.66 & -9657.51 & 322.9 & 979641.18 & 49.33 & 0.04 & 0.13 & 12.90 & 45.61 \\
\hline GEM167 & 3431.05 & -9651.54 & 381.2 & 979626.62 & 52.21 & 0.02 & 0.22 & 9.27 & 41.51 \\
\hline GEM168 & 3433.85 & -9651.72 & 368.3 & 979627.99 & 45.66 & 0.02 & 0.18 & 4.15 & 36.75 \\
\hline GEM169 & 3432.98 & -9653.30 & 366.3 & 979630.78 & 49.08 & 0.02 & 0.18 & 7.78 & 40.44 \\
\hline GEM170 & 3432.10 & -9653.42 & 355.8 & 979632.80 & 49.08 & 0.02 & 0.16 & 8.96 & 41.53 \\
\hline GEM171 & 3430.52 & -9656.99 & 314.1 & 979642.58 & 48.21 & 0.07 & 0.15 & 12.80 & 45.46 \\
\hline GEM172 & 3430.48 & -9656.81 & 332.0 & 979638.45 & 49.67 & 0.06 & 0.17 & 12.24 & 44.88 \\
\hline GEM173 & 3430.40 & -9656.47 & 345.8 & 979635.91 & 51.51 & 0.08 & 0.21 & 12.56 & 45.16 \\
\hline GEM174 & 3430.45 & -9656.60 & 340.6 & 979637.34 & 51.25 & 0.07 & 0.19 & 12.88 & 45.49 \\
\hline GEM175 & 3430.42 & -9656.72 & 335.6 & 979637.83 & 50.26 & 0.05 & 0.16 & 12.42 & 45.04 \\
\hline GEM176 & 3429.43 & -9659.45 & 278.8 & 979647.01 & 43.28 & 0.05 & 0.09 & 11.81 & 44.50 \\
\hline GEM177 & 3429.25 & -9659.34 & 275.4 & 979647.25 & 42.72 & 0.15 & 0.20 & 11.73 & 44.39 \\
\hline GEM178 & 3429.35 & -9659.37 & 273.8 & 979647.58 & 42.44 & 0.10 & 0.15 & 11.58 & 44.25 \\
\hline GEM179 & 3430.19 & -9658.28 & 285.3 & 979648.40 & 45.61 & 0.08 & 0.14 & 13.44 & 46.15 \\
\hline GEM180 & 3430.33 & -9657.25 & 308.9 & 979643.55 & 47.86 & 0.07 & 0.15 & 13.03 & 45.68 \\
\hline GEM181 & 3430.80 & -9658.88 & 298.4 & 979646.60 & 47.00 & 0.02 & 0.07 & 13.28 & 46.11 \\
\hline GEM182 & 3431.04 & -9658.13 & 296.7 & 979646.94 & 46.49 & 0.03 & 0.09 & 12.97 & 45.78 \\
\hline GEM183 & 3430.76 & -9657.28 & 328.1 & 979639.83 & 49.44 & 0.04 & 0.14 & 12.43 & 45.14 \\
\hline GEM184 & 3430.59 & -9657.22 & 332.6 & 979638.62 & 49.87 & 0.08 & 0.19 & 12.40 & 45.08 \\
\hline GEM185 & 3430.71 & -9659.42 & 298.1 & 979646.61 & 47.04 & 0.02 & 0.07 & 13.35 & 46.20 \\
\hline GEM186 & 3430.65 & -9658.59 & 291.1 & 979647.87 & 46.23 & 0.03 & 0.08 & 13.35 & 46.14 \\
\hline GEM187 & 3431.25 & -9658.83 & 306.3 & 979644.94 & 47.15 & 0.02 & 0.08 & 12.54 & 45.42 \\
\hline GEM188 & 3430.35 & -9659.49 & 294.3 & 979646.79 & 46.57 & 0.02 & 0.06 & 13.31 & 46.12 \\
\hline GEM189 & 3430.05 & -9657.49 & 304.4 & 979644.35 & 47.67 & 0.06 & 0.13 & 13.33 & 45.96 \\
\hline GEM190 & 3430.15 & -9657.38 & 307.0 & 979644.00 & 47.98 & 0.06 & 0.14 & 13.35 & 45.98 \\
\hline GEM191 & 3430.05 & -9657.62 & 297.9 & 979644.86 & 46.18 & 0.10 & 0.17 & 12.61 & 45.25 \\
\hline GEM192 & 3430.27 & -9657.09 & 317.0 & 979641.49 & 48.37 & 0.06 & 0.15 & 12.62 & 45.25 \\
\hline GEM193 & 3430.34 & -9657.02 & 327.9 & 979640.18 & 50.34 & 0.14 & 0.24 & 13.45 & 46.08 \\
\hline GEM194 & 3430.45 & -9657.03 & 314.5 & 979642.71 & 48.56 & 0.08 & 0.17 & 13.12 & 45.77 \\
\hline GEM195 & 3430.41 & -9657.18 & 313.0 & 979642.53 & 47.99 & 0.07 & 0.15 & 12.70 & 45.36 \\
\hline GEM196 & 3430.22 & -9657.35 & 306.2 & 979643.72 & 47.36 & 0.08 & 0.16 & 12.84 & 45.48 \\
\hline GEM197 & 3430.31 & -9657.13 & 317.7 & 979641.86 & 48.91 & 0.06 & 0.15 & 13.08 & 45.72 \\
\hline GEM198 & 3430.39 & -9657.39 & 310.0 & 979641.99 & 46.56 & 0.08 & 0.16 & 11.61 & 44.28 \\
\hline GEM199 & 3430.32 & -9657.36 & 309.6 & 979642.95 & 47.50 & 0.06 & 0.14 & 12.57 & 45.22 \\
\hline GEM200 & 3430.10 & -9657.83 & 294.8 & 979645.89 & 46.18 & 0.08 & 0.15 & 12.94 & 45.61 \\
\hline GEM201 & 3430.16 & -9658.19 & 288.9 & 979647.74 & 46.11 & 0.07 & 0.13 & 13.52 & 46.22 \\
\hline GEM202 & 3430.06 & -9658.14 & 304.8 & 979645.06 & 48.48 & 0.08 & 0.15 & 14.11 & 46.79 \\
\hline GEM203 & 3429.80 & -9658.19 & 315.3 & 979641.14 & 48.16 & 0.05 & 0.13 & 12.58 & 45.23 \\
\hline GEM204 & 3430.17 & -9657.29 & 308.0 & 979643.50 & 47.75 & 0.08 & 0.16 & 13.03 & 45.66 \\
\hline GEM205 & 3430.08 & -9657.31 & 310.1 & 979642.39 & 47.41 & 0.17 & 0.25 & 12.55 & 45.17 \\
\hline GEM206 & 3429.97 & -9657.44 & 310.1 & 979642.38 & 47.57 & 0.07 & 0.15 & 12.60 & 45.22 \\
\hline GEM207 & 3430.00 & -9657.66 & 313.6 & 979642.36 & 48.57 & 0.14 & 0.22 & 13.28 & 45.92 \\
\hline GEM208 & 3429.92 & -9657.86 & 311.9 & 979642.31 & 48.12 & 0.05 & 0.13 & 12.92 & 45.56 \\
\hline GEM209 & 3429.96 & -9658.08 & 300.3 & 979644.97 & 47.14 & 0.07 & 0.13 & 13.27 & 45.94 \\
\hline GEM210 & 3429.90 & -9658.04 & 308.3 & 979643.02 & 47.74 & 0.05 & 0.12 & 12.95 & 45.60 \\
\hline GEM211 & 3429.77 & -9657.96 & 322.3 & 979640.74 & 49.96 & 0.05 & 0.14 & 13.61 & 46.24 \\
\hline GEM212 & 3429.68 & -9657.86 & 323.2 & 979640.24 & 49.87 & 0.05 & 0.14 & 13.42 & 46.02 \\
\hline GEM213 & 3430.36 & -9658.90 & 297.5 & 979646.33 & 47.08 & 0.02 & 0.07 & 13.46 & 46.23 \\
\hline GEM214 & 3427.45 & -9701.74 & 305.8 & 979637.11 & 44.50 & 0.14 & 0.20 & 10.07 & 42.64 \\
\hline GEM215 & 3428.07 & -9701.62 & 305.3 & 979637.09 & 43.46 & 0.09 & 0.15 & 9.03 & 41.67 \\
\hline GEM216 & 3428.56 & -9701.35 & 307.5 & 979637.60 & 43.97 & 0.11 & 0.17 & 9.32 & 42.01 \\
\hline GEM217 & 3429.17 & -9700.96 & 313.4 & 979637.87 & 45.20 & 0.08 & 0.15 & 9.86 & 42.61 \\
\hline GEM218 & 3429.19 & -9700.42 & 306.1 & 979640.35 & 45.41 & 0.07 & 0.13 & 10.86 & 43.58 \\
\hline GEM219 & 3430.24 & -9700.16 & 298.4 & 979644.07 & 45.26 & 0.02 & 0.06 & 11.53 & 44.36 \\
\hline
\end{tabular}




\begin{tabular}{|c|c|c|c|c|c|c|c|c|c|}
\hline GEM220 & 3430.37 & -9658.60 & 288.2 & 979648.24 & 46.11 & 0.03 & 0.08 & 13.56 & 46.32 \\
\hline GEM221 & 3428.40 & -9702.28 & 290.7 & 979639.55 & 40.95 & 0.07 & 0.10 & 8.13 & 40.87 \\
\hline GEM222 & 3428.57 & -9702.02 & 267.7 & 979645.22 & 39.30 & 0.07 & 0.09 & 9.06 & 41.81 \\
\hline GEM223 & 3428.63 & -9703.31 & 305.3 & 979635.39 & 40.97 & 0.05 & 0.11 & 6.51 & 39.35 \\
\hline GEM224 & 3429.50 & -9703.19 & 297.1 & 979637.49 & 39.33 & 0.05 & 0.09 & 5.77 & 38.71 \\
\hline GEM225 & 3429.28 & -9702.00 & 274.1 & 979643.94 & 38.99 & 0.04 & 0.06 & 8.00 & 40.84 \\
\hline GEM226 & 3430.02 & -9702.25 & 289.7 & 979641.59 & 40.41 & 0.04 & 0.07 & 7.67 & 40.62 \\
\hline GEM227 & 3426.01 & -9702.03 & 244.4 & 979649.23 & 39.70 & 0.14 & 0.16 & 12.18 & 44.57 \\
\hline GEM228 & 3426.33 & -9703.03 & 278.8 & 979642.95 & 43.60 & 0.09 & 0.11 & 12.13 & 44.64 \\
\hline GEM229 & 3426.87 & -9703.29 & 306.8 & 979634.67 & 43.20 & 0.11 & 0.18 & 8.64 & 41.25 \\
\hline GEM230 & 3427.24 & -9702.99 & 269.5 & 979642.56 & 39.06 & 0.12 & 0.13 & 8.67 & 41.31 \\
\hline GEM231 & 3427.76 & -9703.33 & 290.7 & 979637.21 & 39.50 & 0.04 & 0.07 & 6.65 & 39.38 \\
\hline GEM232 & 3434.00 & -9655.76 & 331.2 & 979637.53 & 43.55 & 0.03 & 0.13 & 6.18 & 39.16 \\
\hline GEM233 & 3437.33 & -9651.20 & 377.7 & 979628.67 & 44.36 & 0.02 & 0.20 & 1.79 & 34.62 \\
\hline GEM234 & 3433.43 & -9650.68 & 382.2 & 979625.23 & 47.81 & 0.02 & 0.21 & 4.74 & 37.17 \\
\hline GEM235 & 3430.52 & -9657.05 & 312.9 & 979642.51 & 47.78 & 0.09 & 0.17 & 12.52 & 45.18 \\
\hline GEM236 & 3430.99 & -9654.87 & 366.2 & 979630.81 & 51.86 & 0.02 & 0.19 & 10.59 & 43.14 \\
\hline GEM237 & 3431.39 & -9654.88 & 360.4 & 979633.35 & 52.04 & 0.02 & 0.17 & 11.42 & 44.02 \\
\hline GEM238 & 3431.81 & -9654.88 & 371.6 & 979631.54 & 53.10 & 0.05 & 0.23 & 11.27 & 43.92 \\
\hline GEM239 & 3432.09 & -9654.88 & 359.0 & 979633.55 & 50.84 & 0.05 & 0.20 & 10.39 & 43.08 \\
\hline GEM240 & 3430.38 & -9654.88 & 350.5 & 979633.33 & 50.41 & 0.02 & 0.15 & 10.87 & 43.34 \\
\hline GEM241 & 3427.77 & -9654.93 & 345.1 & 979635.28 & 54.34 & 0.02 & 0.15 & 15.42 & 47.51 \\
\hline GEM242 & 3428.17 & -9654.93 & 336.7 & 979634.41 & 50.32 & 0.08 & 0.19 & 12.39 & 44.54 \\
\hline GEM243 & 3428.68 & -9654.93 & 348.9 & 979631.26 & 50.23 & 0.04 & 0.17 & 10.90 & 43.13 \\
\hline GEM244 & 3429.43 & -9654.93 & 344.9 & 979631.10 & 47.77 & 0.05 & 0.17 & 8.90 & 41.24 \\
\hline GEM245 & 3429.91 & -9654.93 & 350.9 & 979632.03 & 49.90 & 0.03 & 0.16 & 10.33 & 42.74 \\
\hline GEM246 & 3430.63 & -9654.87 & 354.2 & 979632.70 & 50.56 & 0.02 & 0.16 & 10.62 & 43.12 \\
\hline GEM247 & 3427.70 & -9653.77 & 327.6 & 979637.90 & 51.66 & 0.02 & 0.12 & 14.69 & 46.66 \\
\hline GEM248 & 3428.05 & -9653.89 & 329.2 & 979637.20 & 50.98 & 0.02 & 0.12 & 13.82 & 45.86 \\
\hline GEM249 & 3428.53 & -9653.88 & 338.0 & 979633.19 & 49.01 & 0.03 & 0.14 & 10.88 & 42.99 \\
\hline GEM250 & 3428.90 & -9653.88 & 344.0 & 979632.98 & 50.12 & 0.02 & 0.14 & 11.32 & 43.49 \\
\hline GEM251 & 3429.42 & -9653.88 & 347.5 & 979631.82 & 49.32 & 0.02 & 0.15 & 10.12 & 42.36 \\
\hline GEM252 & 3429.84 & -9653.88 & 355.8 & 979631.96 & 51.42 & 0.02 & 0.16 & 11.30 & 43.61 \\
\hline GEM253 & 3430.20 & -9653.88 & 357.5 & 979631.84 & 51.33 & 0.02 & 0.17 & 11.02 & 43.38 \\
\hline GEM254 & 3430.45 & -9653.82 & 354.0 & 979632.20 & 50.26 & 0.03 & 0.17 & 10.34 & 42.73 \\
\hline GEM255 & 3430.36 & -9652.77 & 375.3 & 979628.42 & 53.18 & 0.04 & 0.23 & 10.91 & 43.18 \\
\hline GEM256 & 3430.35 & -9651.62 & 371.4 & 979628.84 & 52.40 & 0.02 & 0.20 & 10.55 & 42.71 \\
\hline GEM257 & 3431.99 & -9651.22 & 379.8 & 979627.05 & 50.88 & 0.02 & 0.21 & 8.10 & 40.43 \\
\hline GEM258 & 3437.31 & -9639.61 & 305.7 & 979638.26 & 31.76 & 0.07 & 0.18 & -2.68 & 28.24 \\
\hline GEM259 & 3435.58 & -9646.47 & 362.8 & 979630.18 & 43.74 & 0.03 & 0.19 & 2.85 & 34.92 \\
\hline GEM260 & 3432.97 & -9648.51 & 361.8 & 979629.06 & 45.96 & 0.03 & 0.18 & 5.19 & 37.31 \\
\hline GEM261 & 3430.66 & -9658.23 & 288.7 & 979647.49 & 45.11 & 0.06 & 0.12 & 12.53 & 45.30 \\
\hline GEM262 & 3428.83 & -9657.55 & 346.8 & 979632.35 & 50.47 & 0.04 & 0.18 & 11.38 & 43.83 \\
\hline GEM263 & 3426.02 & -9658.40 & 294.8 & 979636.29 & 42.29 & 0.07 & 0.12 & 9.03 & 41.13 \\
\hline GEM264 & 3426.23 & -9700.48 & 268.5 & 979641.80 & 39.41 & 0.03 & 0.05 & 9.05 & 41.35 \\
\hline GEM265 & 3426.14 & -9700.15 & 280.7 & 979639.22 & 40.71 & 0.06 & 0.09 & 9.01 & 41.26 \\
\hline GEM266 & 3426.52 & -9659.13 & 285.4 & 979638.05 & 40.47 & 0.06 & 0.10 & 8.25 & 40.49 \\
\hline GEM267 & 3427.11 & -9659.13 & 302.1 & 979636.05 & 42.78 & 0.05 & 0.11 & 8.68 & 41.01 \\
\hline GEM268 & 3427.70 & -9658.78 & 318.9 & 979638.81 & 49.90 & 0.03 & 0.12 & 13.91 & 46.30 \\
\hline GEM269 & 3427.38 & -9658.08 & 323.0 & 979632.63 & 45.43 & 0.04 & 0.13 & 8.99 & 41.27 \\
\hline GEM270 & 3427.76 & -9657.57 & 329.2 & 979634.53 & 48.72 & 0.04 & 0.14 & 11.58 & 43.87 \\
\hline GEM271 & 3427.97 & -9657.04 & 331.5 & 979635.93 & 50.53 & 0.04 & 0.15 & 13.14 & 45.43 \\
\hline GEM272 & 3430.39 & -9658.14 & 297.8 & 979646.17 & 46.95 & 0.04 & 0.10 & 13.33 & 46.05 \\
\hline GEM273 & 3429.45 & -9657.45 & 327.9 & 979637.96 & 49.37 & 0.06 & 0.16 & 12.40 & 44.94 \\
\hline GEM274 & 3428.63 & -9656.39 & 363.3 & 979629.49 & 52.98 & 0.07 & 0.25 & 12.09 & 44.42 \\
\hline GEM275 & 3425.33 & -9655.98 & 323.0 & 979638.18 & 53.87 & 0.09 & 0.19 & 17.48 & 49.25 \\
\hline GEM276 & 3423.83 & -9648.64 & 311.4 & 979632.23 & 46.44 & 0.02 & 0.11 & 11.29 & 42.00 \\
\hline GEM277 & 3422.61 & -9647.59 & 290.2 & 979637.84 & 47.21 & 0.03 & 0.10 & 14.45 & 44.79 \\
\hline
\end{tabular}




\begin{tabular}{|c|c|c|c|c|c|c|c|c|c|}
\hline GEM278 & 3425.16 & $\begin{array}{l}-9647.59 \\
\end{array}$ & 344.9 & 979630.17 & 52.84 & 0.03 & 0.18 & 13.98 & 44.80 \\
\hline GEM279 & 3427.72 & -9647.59 & 336.9 & 979633.80 & 50.42 & 0.02 & 0.14 & 12.41 & 43.68 \\
\hline GEM280 & 3427.77 & -9652.83 & 330.2 & 979636.93 & 51.40 & 0.02 & 0.13 & 14.14 & 46.04 \\
\hline GEM281 & 3428.63 & -9655.25 & 367.0 & 979628.75 & 53.38 & 0.06 & 0.24 & 12.07 & 44.31 \\
\hline GEM282 & 3428.64 & $\begin{array}{l}-9654.39 \\
\end{array}$ & 338.0 & 979633.88 & 49.54 & 0.03 & 0.14 & 11.41 & 43.58 \\
\hline GEM283 & 3428.64 & -9653.34 & 335.5 & 979635.22 & 50.10 & 0.01 & 0.12 & 12.23 & 44.31 \\
\hline GEM284 & 3430.04 & -9653.88 & 360.4 & 979630.96 & 51.57 & 0.03 & 0.18 & 10.95 & 43.28 \\
\hline GEM285 & 3430.33 & -9653.43 & 355.6 & 979631.72 & 50.43 & 0.02 & 0.16 & 10.33 & 42.67 \\
\hline GEM286 & 3429.98 & -9652.83 & 356.6 & 979631.33 & 50.83 & 0.03 & 0.17 & 10.64 & 42.88 \\
\hline GEM287 & 3429.68 & -9652.91 & 356.2 & 979631.38 & 51.19 & 0.03 & 0.17 & 11.04 & 43.24 \\
\hline GEM288 & 3429.53 & -9653.46 & 356.5 & 979632.44 & 52.56 & 0.03 & 0.18 & 12.37 & 44.59 \\
\hline GEM289 & 3429.36 & -9653.48 & 344.8 & 979632.29 & 49.03 & 0.02 & 0.14 & 10.14 & 42.34 \\
\hline GEM290 & 3429.08 & -9653.10 & 350.0 & 979631.67 & 50.40 & 0.02 & 0.15 & 10.93 & 43.05 \\
\hline GEM291 & 3429.70 & -9653.88 & 351.9 & 979632.99 & 51.44 & 0.02 & 0.16 & 11.75 & 44.04 \\
\hline GEM292 & 3429.51 & -9654.38 & 339.4 & 979632.95 & 47.83 & 0.02 & 0.14 & 9.53 & 41.84 \\
\hline GEM293 & 3429.72 & -9654.93 & 347.8 & 979631.55 & 48.71 & 0.03 & 0.16 & 9.49 & 41.87 \\
\hline GEM294 & 3429.50 & -9655.47 & 355.1 & 979629.78 & 49.50 & 0.02 & 0.17 & 9.47 & 41.87 \\
\hline GEM295 & 3429.50 & -9656.03 & 370.6 & 979627.68 & 52.20 & 0.05 & 0.25 & 10.49 & 42.92 \\
\hline GEM296 & 3429.49 & -9656.73 & 336.0 & 979634.78 & 48.64 & 0.06 & 0.17 & 10.76 & 43.25 \\
\hline GEM297 & 3427.98 & -9659.12 & 323.6 & 979637.98 & 50.13 & 0.04 & 0.14 & 13.62 & 46.07 \\
\hline GEM298 & 3428.27 & -9658.69 & 332.4 & 979636.53 & 51.00 & 0.04 & 0.16 & 13.51 & 45.97 \\
\hline GEM299 & 3428.75 & -9659.01 & 321.4 & 979638.37 & 48.76 & 0.10 & 0.19 & 12.55 & 45.11 \\
\hline GEM300 & 3428.86 & -9659.72 & 289.7 & 979644.00 & 44.45 & 0.07 & 0.11 & 11.75 & 44.37 \\
\hline GEM301 & 3428.92 & -9659.38 & 302.3 & 979642.09 & 46.33 & 0.07 & 0.13 & 12.23 & 44.83 \\
\hline GEM302 & 3429.08 & -9658.97 & 312.3 & 979639.56 & 46.66 & 0.07 & 0.14 & 11.44 & 44.04 \\
\hline GEM303 & 3429.26 & -9659.11 & 300.8 & 979642.31 & 45.62 & 0.06 & 0.12 & 11.67 & 44.31 \\
\hline GEM304 & 3430.43 & -9659.81 & 290.8 & 979647.56 & 46.13 & 0.02 & 0.06 & 13.26 & 46.10 \\
\hline GEM305 & 3429.71 & -9657.80 & 323.5 & 979640.08 & 49.75 & 0.05 & 0.14 & 13.26 & 45.86 \\
\hline GEM306 & 3429.76 & $\begin{array}{l}-9657.59 \\
\end{array}$ & 320.0 & 979640.37 & 48.89 & 0.06 & 0.15 & 12.81 & 45.41 \\
\hline GEM307 & 3429.58 & -9657.71 & 331.3 & 979638.00 & 50.29 & 0.06 & 0.16 & 12.93 & 45.51 \\
\hline GEM308 & 3430.07 & -9658.49 & 292.2 & 979646.81 & 46.31 & 0.05 & 0.11 & 13.33 & 46.04 \\
\hline GEM309 & 3429.74 & -9658.42 & 310.6 & 979642.00 & 47.66 & 0.05 & 0.12 & 12.61 & 45.27 \\
\hline GEM310 & 3429.81 & -9658.35 & 311.9 & 979642.16 & 48.12 & 0.05 & 0.12 & 12.92 & 45.58 \\
\hline GEM311 & 3429.86 & -9658.29 & 311.4 & 979643.05 & 48.80 & 0.05 & 0.12 & 13.65 & 46.32 \\
\hline GEM312 & 3430.05 & -9657.90 & 301.0 & 979644.38 & 46.65 & 0.07 & 0.14 & 12.70 & 45.37 \\
\hline GEM313 & 3430.14 & -9658.01 & 302.7 & 979644.51 & 47.17 & 0.06 & 0.13 & 13.02 & 45.70 \\
\hline GEM314 & 3430.22 & -9658.09 & 295.2 & 979645.84 & 46.07 & 0.07 & 0.13 & 12.77 & 45.47 \\
\hline GEM315 & 3430.17 & -9658.08 & 299.0 & 979645.10 & 46.58 & 0.05 & 0.11 & 12.83 & 45.53 \\
\hline GEM316 & 3430.04 & -9658.60 & 287.8 & 979648.09 & 46.29 & 0.05 & 0.10 & 13.80 & 46.51 \\
\hline GEM317 & 3429.97 & -9658.65 & 291.2 & 979647.92 & 47.27 & 0.05 & 0.10 & 14.40 & 47.10 \\
\hline GEM318 & 3429.89 & $\begin{array}{l}-9658.71 \\
\end{array}$ & 282.0 & 979648.42 & 45.05 & 0.11 & 0.16 & 13.28 & 45.98 \\
\hline GEM319 & 3430.07 & -9658.49 & 291.7 & 979647.15 & 46.51 & 0.06 & 0.12 & 13.59 & 46.30 \\
\hline GEM320 & 3430.43 & $\begin{array}{l}-9659.81 \\
\end{array}$ & 290.5 & 979647.73 & 46.21 & 0.02 & 0.06 & 13.37 & 46.21 \\
\hline GEM321 & 3428.90 & -9659.01 & 316.0 & 979639.33 & 47.85 & 0.08 & 0.16 & 12.22 & 44.8 \\
\hline GEM322 & 3429.08 & -9658.97 & 314.4 & 979639.64 & 47.41 & 0.09 & 0.16 & 11.97 & 44.57 \\
\hline GEM323 & 3429.18 & -9659.06 & 306.7 & 979641.14 & 46.38 & 0.06 & 0.12 & 11.77 & 44.39 \\
\hline GEM324 & 3427.65 & -9657.03 & 332.7 & 979634.74 & 50.14 & 0.04 & 0.15 & 12.63 & 44.87 \\
\hline GEM325 & 3428.51 & -9657.34 & 355.6 & 979631.15 & 52.42 & 0.04 & 0.21 & 12.37 & 44.75 \\
\hline GEM326 & 3429.21 & -9657.79 & 328.8 & 979636.55 & 48.56 & 0.10 & 0.20 & 11.53 & 44.06 \\
\hline GEM327 & 3429.73 & -9658.12 & 317.7 & 979641.32 & 49.18 & 0.04 & 0.12 & 13.33 & 45.96 \\
\hline
\end{tabular}


Table A2. Physical property measurements of rock samples collected in 2004 and 2005

\begin{tabular}{|c|c|c|c|c|c|c|c|}
\hline Station & Rock type & $\begin{array}{l}\text { Circular } \\
91 \text { code }^{1}\end{array}$ & $\begin{array}{c}\text { Grain } \\
\text { density } \\
\left(\mathrm{g} / \mathrm{cm}^{3}\right)\end{array}$ & $\begin{array}{c}\text { Saturated } \\
\text { bulk density } \\
\left(\mathrm{g} / \mathrm{cm}^{3}\right)\end{array}$ & $\begin{array}{c}\text { Dry bulk } \\
\text { density } \\
\left(\mathrm{g} / \mathrm{cm}^{3}\right)\end{array}$ & $\begin{array}{c}\text { Porosity } \\
(\%)\end{array}$ & $\begin{array}{c}\text { Susceptibility } \\
\left(10^{-3} \mathrm{SI}\right)\end{array}$ \\
\hline GEM149 & Sandstone & Owk & 2.67 & 2.62 & 2.59 & 3.1 & 0.02 \\
\hline GEM150 & Carbonate & Owk & 2.77 & 2.67 & 2.62 & 5.9 & 0.03 \\
\hline GEM151 & Carbonate & Owk & 2.76 & 2.64 & 2.58 & 7.0 & 0.03 \\
\hline GEM152 & Carbonate & Ooj & 2.50 & 2.30 & 2.17 & 14.9 & 0.02 \\
\hline GEM158 & Carbonate & Obm & 2.68 & 2.66 & 2.66 & 0.9 & 0.02 \\
\hline GEM173 & Conglomerate & $\mathrm{IPvc}$ & 2.64 & 2.56 & 2.51 & 5.0 & 0.01 \\
\hline GEM175A & Arkose & $\mathrm{IPvc}$ & 2.49 & 2.36 & 2.27 & 10.0 & 0.01 \\
\hline GEM175B & Conglomerate & IPvc & 2.65 & 2.59 & 2.56 & 3.3 & 0.02 \\
\hline GEM205 & Arkose & $\mathrm{IPvc}$ & 2.38 & 2.24 & 2.14 & 11.5 & 0.03 \\
\hline GEM241 & Carbonate & Owk & 2.75 & 2.70 & 2.67 & 3.1 & 0.05 \\
\hline GEM244 & Carbonate & Obm & 2.67 & 2.65 & 2.64 & 1.2 & 0.01 \\
\hline GEM254 & Carbonate & $\mathrm{Ow}$ & 2.77 & 2.69 & 2.64 & 4.9 & 0.03 \\
\hline GEM267 & Carbonate & Osv & 2.67 & 2.66 & 2.65 & 0.7 & 0.01 \\
\hline GEM275 & Carbonate & MDsw & 2.64 & 2.59 & 2.55 & 3.5 & 0.02 \\
\hline GEM278 & Sandstone & Ocm & 2.71 & 2.69 & 2.68 & 1.3 & 0.03 \\
\hline GEM286 & Carbonate & $\mathrm{Ow}$ & 2.81 & 2.80 & 2.79 & 0.6 & 0.02 \\
\hline GEM296 & Arkose & IPvc & 2.54 & 2.45 & 2.40 & 6.1 & 0.02 \\
\hline GEM326 & Carbonate & Obm & 2.67 & 2.63 & 2.62 & 1.9 & 0.02 \\
\hline GEM1000 & Carbonate & $\mathrm{Ow}$ & 2.66 & 2.55 & 2.49 & 6.8 & 0.04 \\
\hline GEM1001 & Carbonate & $\mathrm{Ow}$ & 2.75 & 2.66 & 2.61 & 5.6 & 0.04 \\
\hline GEM1002 & Granite & $\mathrm{pCgg}$ & 2.62 & 2.58 & 2.56 & 2.3 & 2.1 \\
\hline GEM1101 & Carbonate & $\mathrm{Ow}$ & 2.72 & 2.71 & 2.70 & 0.7 & 0.02 \\
\hline GEM1102 & Carbonate & DSOh & 2.63 & 2.57 & 2.53 & 3.9 & 0.07 \\
\hline GEM1103 & Sandstone & Obm & 2.37 & 2.26 & 2.18 & 8.8 & 0.05 \\
\hline GEM1104 & Granite & $\mathrm{pCtr}$ & 2.64 & 2.64 & 2.63 & 0.3 & 9.4 \\
\hline GEM1105 & Sandstone & Obm & 2.47 & 2.40 & 2.36 & 4.7 & 0.03 \\
\hline GEM1106 & Carbonate & Osv & 2.67 & 2.66 & 2.65 & 0.8 & 0.04 \\
\hline GEM1107 & Granite & pCgr & 2.83 & 2.82 & 2.81 & 0.8 & 22 \\
\hline GEM1108 & Granite & pCti & 2.61 & 2.60 & 2.60 & 0.5 & 0.45 \\
\hline GEM1109 & Shale & MDsw & 2.48 & 2.45 & 2.44 & 1.8 & 0.01 \\
\hline
\end{tabular}

${ }^{1}$ Circular 91 denotes Plate 1 of Fairchild and others (1990). 